\title{
Contributions to the Life-history of Actinostrobus pyramidalis, Miq.
}

\author{
BY \\ W. T. SAXTON, M.A., F.L.S. \\ Lecturer in Botany at the South African College, Cape Town.
}

With Plates XXV-XXVIII and three Figures in the Text.

$\mathrm{T}$ HE genus Actinostrobus, Miq., consists of two species of small trees or shrubs confined to Western Australia. Actinostrobus pyramidalis is fairly common in the neighbourhood of Perth, but Actinostrobus acuminatus, Parlat., is less easily accessible, though locally common on the sand plains between the Moore and Murchison Rivers. It has not been possible to secure fixed material of the last-named species, but from a study of herbarium specimens it is evident that it is very closely related to $A$. pyramidalis and would be extremely unlikely to show structural differences of much importance.

The present study is a continuation of the series of investigations on the structure and development of the Callitrineae, accounts of Widdringtonia and Callitris having been already published $(19,20,21)$. A very small amount of the material for this investigation was collected in January and February, I9I0, from a small tree in the temperate house, Kew Gardens, and for facilities in connexion with these collections thanks are due to Mr. Boodle, Keeper of the Jodrell Laboratory, Kew.

By far the larger number of collections were, however, made for me, and I am glad to take this opportunity of thanking very heartily Dr. A. Morrison, late Government Botanist in Western Australia, for the great trouble he has taken in securing and fixing material for me in all stages of development. He has also placed at my disposal some excellent dried specimens of both species of the genus, and has given me interesting information in regard to the time of pollination, \&c., which has formed the basis of the 'field notes' below. Without his assistance the greater part of this study would have been impossible. Thanks are also due to Mr. Stiles, who handed over to me some material collected by him at Kew and Cambridge Botanic Gardens with a view to working on the genus. This material, however, as well as that collected by myself, did not yield anything except quite early stages, as, although pollen is plentiful, all female cones on the plants growing there become abortive.

[Annals of Botany, Vol. XXVII. No. CVI. April, 19r3.] 
Field Notes, \&C.

The plants of Actinostrobus pyramidalis growing in the neighbourhood of Perth are seldom above io feet high, and have a very similar habit to small trees of Callitris. The persistence of the old cones is a characteristic feature; Dr. Morrison informs me that they remain attached to the stems for several years before shedding their seeds, on the main stem and two or three grades of branches.

It seems probable that female cones, and perhaps a few male cones, may make their appearance at various seasons of the year, but the normal crop of young cones appears about May or June. Pollination takes place from June to August, the pollen being shed from one tree after another, in an apparently gradual succession. From the development of the ovules, however, it seems fairly certain that effective pollination only occurs about the first half of July. Dr. Morrison records the very interesting observation that a drop of fluid may be seen extruded from the open micropyle of the young ovules, in which doubtless the pollen-grains are caught and subsequently withdrawn on to the nucellus. Of the various devices facilitating pollination in Conifers, this would appear from the rather scanty records to be the commonest. The pollination drop has also recently been observed by the writer in Widdringtonia. In Callitris, ovules young enough to be likely to show this phenomenon have not at present been seen.

Approximately three months elapse between pollination and fertilization, the latter occurring about the second week in October. Fertilization is not so nearly simultaneous in different ovules as it is in Pimus and some other genera, but probably does not vary more than about a week, on either side of the average. It is interesting to note that although the winter seasons of I9IO and I9I I were very different, especially as regards rainfall, the average date of fertilization did not differ appreciably, collections covering that event having been made on October I2, I9IO, and October 9, I9I"I.

Unlike some Conifers, in which the cones are often almost full grown at the time of fertilization, Actinostrobus cones are only about two-thirds of their mature size at that time. They attain their full size about a month later, when they can only be distinguished from previous years' cones by their green colour.

The female cones are terminal on very short branchlets, these being borne in the axils of foliage leaves near the base of a young branch. At the time when pollination takes place the cone scales are not widely spreading as they are in other Callitrineae, but are evidently prevented from diverging by the closely appressed barren scales of the cone. After pollination the fertile scales rapidly increase in size, and grow together over the top of the cone in the manner recently described for Callitris by Baker and 
Smith (1). Owing, however, to the fact that the tips of the fertile scales are only slightly divergent, the second (inner) 'apex' is far less conspicuous than in Callitris, the original morphological apex being on a level with it, and more or less hiding it in an external view of the cone.

A median longitudinal section of a cone scale in a three-quarter grown cone is shown in outline in Text-fig. I, indicating the points noted above, and also showing the course of the vascular bundles, and the position of a resin sac. In the Callitrineae the two distinct apices of the mature cone scales cannot be regarded as any evidence of the double nature of those structures; in the young scale only one apex is present, the second being produced, as shown by Baker and Smith (loc. cit.), simply by the bulging inwards and upwards, with mutual pressure, of the inner faces of the fertile scales. Since the authors quoted have carefully described and figured the process, it is not necessary to discuss it further. The two sets of vascular strands are present as usual, as shown in the figure.

Each cone terminates in a central columella, which, as in Callitris, contains a large resin cavity. The seeds are usually threewinged.

The male cones are $5^{-6} \mathrm{~mm}$. in length, or sometimes less, when mature, and are found in the axils of foliage leaves, 6-10 occurring on one branchlet. The sporophylls are in six vertical rows, made up of about nine alternating whorls of three in the larger cones. The sporophylls are regularly peltate, like those of

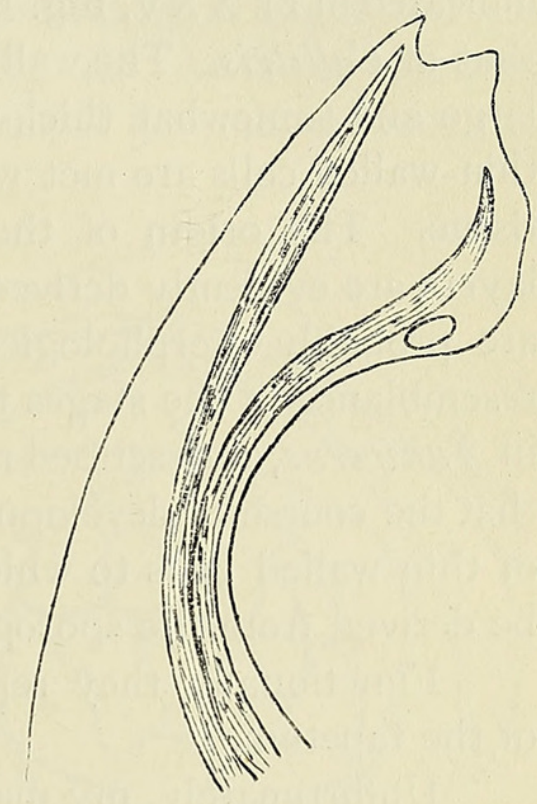

TEXT-Fig. I. Longitudinal section of the upper part of a nearly mature cone scale. $\times 9$.

Widdringtonia and Callitris, the peltate expansion having a brown margin, and the stalk bears usually three sporangia on its proximal side. The axis elongates rapidly at the time of dehiscence of the sporangia, as in many other Conifers, separating the sporophylls, and the sporangia open irregularly.

The plants are monoecious, like other Callitrineae.

\section{LABORATORY INVESTIGATION.}

The methods used in this investigation have been substantially the same as those employed in the study of Callitris. The fixing-agent employed for almost all the collections was the following:

Picric acid (saturated solution in $5 \circ$ per cent. alcohol) . IO० c.c.

Mercuric chloride (corrosive sublimate) .

5 grammes.

Acetic acid (glacial) 
All material for microtome sectioning was embedded through cedar-wood oil, and in the later material it was found possible, with frequent changes of paraffin, to reduce the period in the oven to about four hours.

All microtome sections were cut with a Cambridge rocking microtome to a thickness of about $7 \mu$, and stained with either Delafield's haematoxylin or (usually) Fleming's triple stain. All drawings were made from such sections except Text-fig. I, and Pl. XXV, Figs. I7, I8, and I9, which are from hand sections, and all were made with the camera lucida.

\section{Microsporangium AND Microspores.}

The position of the three sporangia on the stalk of the sporophyll is indicated in Pl. XXV, Fig. I. The structure of the sporangium is exactly like that of Callitris. The wall, when mature, consists of a single layer of rather large and somewhat thick-walled cells, but in younger stages two layers of thin-walled cells are met with between the epidermis and the sporogenous tissue. The origin of these cells has not been determined, but the two layers are evidently derived from a single layer by periclinal divisions, and are probably morphologically part of the sporogenous tissue. The close resemblance in the stages that have been seen to the corresponding stages in Fumiperus, as described recently by Nichols (17), makes it highly probable that the course of development is very similar; in Funiperus the two layers of thin-walled cells to which reference has been made are clearly shown to be derived from the sporogenous tissue.

Functionally they represent at least a part, and probably the whole, of the tapetum.

Unfortunately, my material only includes quite young, and mature or nearly mature, male cones, so that stages to illustrate sporogenesis have been missed. ${ }^{1}$ The mature pollen-grain (Fig. 2) is exactly like that of Widdringtonia and Callitris, and is uninucleate at the time of pollination, the nucleus being surrounded by a layer of rather large starch grains. As seen in section, the exine is thin and the intine rather thick; it is very probable, however, that in the fresh state the real thickness of the intine is considerably less than appears in sections of fixed material. Observations on fresh pollen of related Conifers have indicated the difficulty of preventing considerable swelling of the intine in fixing material; possibly the difficulty might be overcome with special technique.

\section{The Female Cone and the Ovule.}

Text-fig. 2 is a transverse section across a young cone, passing through the base of the ovules. The close resemblance of sterile and fertile scales, when young, is apparent, the innermost whorl bearing generally two ovules

1 Since the above was written I have obtained late stages of spore-formation from cones procured from Kew through the kindness of Mr. L. A. Boodle. These have shown that the tetrad of spores is formed in a mother-cell which, unlike that of Pimus, does not become partitioned. 
to each scale, the scales of the next whorl one ovule each, and all the outer whorls being completely sterile. There is, however, considerable variation in the number of ovules borne in a healthy cone, the minimum and maximum being about six and about twelve respectively.

The young ovule, about the time of pollination (Fig. 3), shows a long and widely open micropyle, and a nucellus free from the integument nearly to the base of the ovule. The integument is rather thick, and the cells which, at a later stage, close the micropyle are clearly defined on its inner surface, these having somewhat denser contents and more conspicuous nuclei than the other cells.

Very soon after this, a single cell near the base of the nucellus becomes differentiated from its neighbours. It is distinguished by a larger and less deeply staining nucleus and denser cytoplasm (Fig. 4). As far as has been seen, never more than one such cell is formed, and it becomes at once the megaspore mother-cell. This agrees closely with the corresponding stage in Callitris, where often only one megaspore mother-cell is formed ; in that genus, however, two or three may be sometimes organized, this being probably co-ordinated with the occasional development of two or three embryo-sacs. In Actinostrobus there is a complete absence, as in Callitris, of any tissue specially differentiated as a tapetum. It seems clear, in spite of differences of opinion on the subject, that the so-called 'spongy tissue' of many Conifers is nothing more nor less than the sporogenous tissue of the megasporangium, generally, if not always, in the mother-cell stage. The

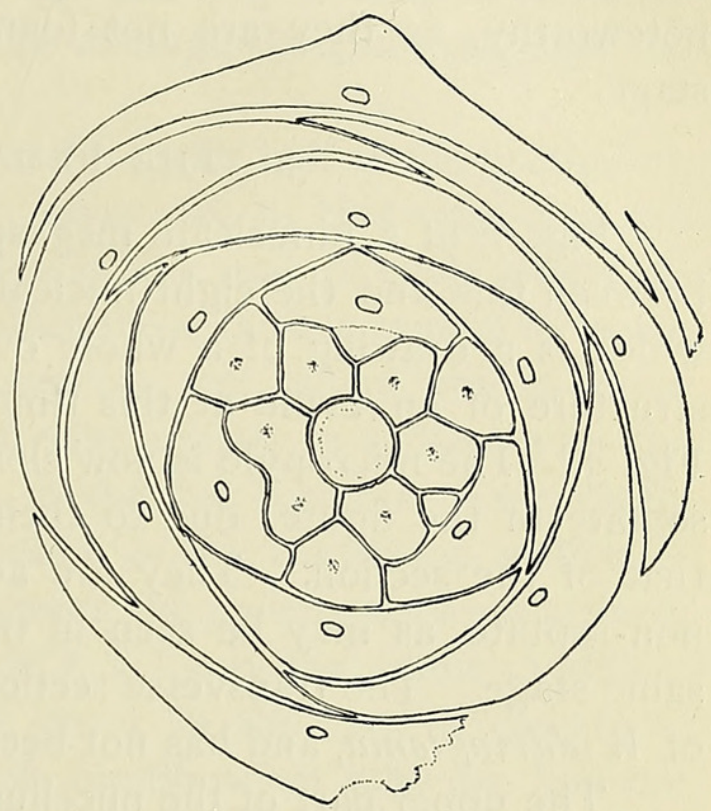

TEXT-FIG. 2. Transverse section across a young female cone. $\times 25$.

case of Widdringtonia and Tetraclinis (figured as Callitris quadrivalvis by Goebel (9)), where the sporogenous cells are absolutely alike until quite shortly before the division of the functional mother-cell, scarcely leaves room for doubt on this point. Bower (2), with special reference to the Cryptogams, has shown how largely sterilization of potentially sporogenous tissue has been responsible for differentiation and advance in the plant kingdom, and the conception of the spongy tissue of Conifers as potentially sporogenous not only co-ordinates more clearly the megasporangium and microsporangium, but also indicates better the undoubted connexion between the gymnosperm ovule and the megasporangium of the higher Cryptogams, where the sterilization of sporogenous tissue is a still more conspicuous 
feature. In Callitris and Actinostrobus we have clearly an advance from the condition found in Widdringtonia, in the fact that sterilization occurs before any differentiation of sporogenous tissue is visible. This is, of course, only theoretical, as there is no means of distinguishing sporogenous tissue until it becomes microscopically visible.

At a slightly later stage than that described above, the mother-cell nucleus is found in synapsis (Fig. 5). At this time the cell has elongated somewhat and its wall has thickened considerably.

Further stages to illustrate the reduction divisions have unfortunately been missed, but Fig. 6, which shows a uninucleate megaspore, indicates that probably three cells, or at least three nuclei, are formed by the divisions of the mother-cell ; but this cannot be stated with any certainty. In any case, the other megaspores very rapidly disorganize, and after one or two divisions in the functional megaspore can no longer be distinguished. The presence of a number of starch grains in the uninucleate megaspore is noteworthy, as they are not found either just before or just after this stage.

\section{The Female Gametophyte.}

Fig. 7 , of a binucleate megaspore, shows that vacuolation only occurs between this and the eight-nucleate stage. The latter is shown in Fig. 8, which is a drawing of a whole ovule, serving also to illustrate the general structure of an ovule at this time as compared with the stage shown in Fig. $3 .{ }^{1}$ The micropyle is now closed, the micropyle-closing cells appearing septate in the figure, due to their growing in a slightly different plane to that of the section. They are actually, however, usually, if not always, non-septate, as may be seen in transverse sections of the micropyle at the same stage. The transverse section closely resembles that of the micropyle of Widdringtonia, and has not been figured.

The upper part of the nucellus consists at this time of cells with thick walls and dense contents. These cells never divide and appear to be dead or dying, and the pollen-tubes do not now extend below this tissue, which is sharply differentiated from the meristematic tissue below it. The young embryo-sac lies a good deal nearer the base of the nucellus than is the case in Callitris, but is not so deeply placed as in Widdringtonia. The cells below the embryo-sac are in somewhat regular longitudinal rows, with dense contents, but are not quite so distinctly differentiated in this respect as are those of Callitris.

The early divisions of the nuclei, which lie in the lining layer of protoplasm in the embryo-sac, are simultaneous, but whether this applies to the later divisions has not been determined.

Cell formation is similar to that in Widdringtonia, alveoli being

1 Fig. 3 and Fig. 8 are not, however, drawn to the same scale. 
organized, each of which, before reaching very far towards the centre of the sac, cuts off a small cell at its base. The form of these small cells is clearly seen in Fig. 9. The alveoli are otherwise quite unsegmented, the apparent transverse walls appearing in the figure in some places, especially on the right, being due to other alveoli passing into the plane of the section. On reaching the centre of the prothallus, each alveolus is terminated by a wall, stages shortly after that represented in Fig. 9 showing, occasionally, the two end walls of opposite alveoli in contact. Apparently, however, they soon fuse together, as only a single wall can be distinguished later.

The apex of the prothallus is narrow and pointed, not truncate or rounded as in most Conifers.

The long inner cells of the alveoli in the upper half of the prothallus, except in the narrow part near the apex, are those from which, after cutting off some small cells at one or both ends, the archegonium initials are formed. Thus the archegonium initials are the largest cells in the prothallus at the time when they can first be distinguished, not amongst the smallest, as is often the case.

It appears as though every alveolus in the upper half of the prothallus, with the exception of the narrow apex, gives rise in this way to a cell which is of the nature of an archegonium initial, and in cases where no pollen-tubes have grown down the prothallus, these initials remain for some time unsegmented and are rather conspicuous, but where one or more normal pollen-tubes have grown down, only the initials in contact with the pollen-tube become functional archegonia, all the rest becoming transversely divided into several cells. This is indicated in the transverse section of a prothallus shown in Fig. Io. Since, however, the pollen-tubes are already in position when cell formation takes place, it is likely that some modification of the method just described must occur in the case of functional archegonium initials. Exactly what this modification may be has not been determined, but enough has been seen to make it clear that the initials always arise in a similar manner to that just described.

In a former paper (19) it was stated that in Widdringtonia the distribution of archegonia is determined largely by the position of the pollen-tube. It was subsequently shown, however, in Callitris (21) that archegonium initials might appear in an exactly similar position, in the absence of a pollen-tube in the prothallus.

The present study makes the position more clear, and as the point is of some importance, the degree of correlation between pollen-tube, archegonia, and archegonium initials may be briefly recapitulated as follows: The formation of archegonium initials in their normal position, laterally and deep-seated in the prothallus, is not determined by the position of the pollen-tube, but this position does determine which of the very numerous archegonium initials become functional archegonia. 
Coulter (4), in a paper reprinted in Coulter and Chamberlain's 'Morphology of Gymnosperms' (5), makes the following statement: 'In cases where the pollen-tube assumes a lateral position in reference to the gametophyte (as in Sequoia and Widdringtonia), it has been demonstrated that the latter responds by the selection of numerous deep-seated and laterally placed archegonium initials.' I am not prepared to say whether, in point of fact, the prothallus of Widdringtonia does, or does not, behave in the way described, but I am not aware of any published work on the genus which justifies a statement that it does behave in this manner. What has been stated, and it applies equally to Callitris and Actinostrobus, is that archegonia (that is, fully formed archegonia, capable of further development when fertilized) are organized only in relation to pollen-tubes. ${ }^{1}$ In another place Coulter and Chamberlain (5) remark, in connexion with Widdringtonia and Callitris, "This position (i. e. of the pollen-tube) seems to determine the selection of archegonium initials, which begin to appear in groups beneath the surface.' This is an equally misleading statement.

Considerable stress has been laid on this point, since it must be emphasized that in Actinostrobus and Callitris, and doubtless also in Widdringtonia, though not proved in that genus, the position of the archegonium initials is a definite character of the female gametophyte, and not merely one correlated with the position of the pollen-tube. Coulter (4), in the paper cited above, apparently also correlates the 'micropylar' position of archegonia in most Conifers with the 'micropylar' position of the tip of the pollen-tube; it is, however, difficult to believe that the selection of archegonium initials in Pinus (to take a definite example) is influenced by the position of a pollen-tube which has only penetrated a short distance down the nucellus, and is still separated by a thick mass of nucellar tissue from the apex of the prothallus. Moreover, occasional abnormal prothalli of Pinus show laterally placed archegonia, without any evidence of a correspondingly placed pollen-tube, while sometimes a pollen-tube takes a very irregular course and enters an archegonium from the side.

The young archegonium of Actinostrobus has a very inconspicuous neck of two cells (Figs. IO, II, I2), and a small nucleus which lies just below the neck. The evidence in regard to the cutting off of a ventral canal nucleus is very meagre. Three cases are figured (Figs. I3, I4, and 33), of which the second and third are almost certainly (the third certainly) abnormal, and the first quite possibly so. Figs. I 3 and I4 are from the same prothallus as the abnormal pollen-tube of Fig. $3^{2}$; and $\mathrm{I}_{3}$ is an

1 The fact that there was some doubt whether all the archegonia in Widdringtonia had undergone any divisions after the 'initial 'stage does not invalidate this statement. I have a preparation of Sequoia, also, which shows a lateral archegonium in a prothallus where no pollen-tube can be found. 
isolated example of an archegonium showing two nuclei in the normal positions of oosphere and ventral canal nuclei, respectively. Nearly all the other archegonia of this prothallus have the structure shown in Fig. I4. This shows apparently a late stage of a division which might be interpreted as that cutting off the ventral canal nucleus, but it has certain peculiarities not characteristic of that division. In the first place, the number of chromosomes at each pole appears to be less in every case than the normal reduced number (eight); secondly, the upper group of chromosomes is very much smaller than the lower in every case, and seems to consist of only one or two chromosomes. The most reasonable interpretation seems to be that the whole ovule is an abnormal one, and that, instead of forming a normal ventral nucleus, the chromosomes of the central nucleus have separated out and discharged one or two of their number from the rest, which have then remained as chromosomes instead of becoming reorganized into a nucleus. If this explanation is more or less correct, it is evident that the occurrence of an apparently normally organized ventral nucleus in a neighbouring archegonium can scarcely be regarded as good evidence that such a body is formed in normal prothalli. The third case is that of an archegonium in which fertilization has already taken place, but which contains what can only be regarded as a ventral canal cell. If such a cell were normally organized, or if (as would be far more probable) a nucleus were formed which persisted for even a few hours, it is reasonably certain that it could not have been missed in normal preparations. A difference in the structure, size, and position of the archegonium nucleus is, however, apparent between the stages shown in Figs. Io and $\mathrm{I} 2$. This is interpreted as being due to the cutting off, between the two stages, of an ephemeral ventral canal nucleus, which completely and very rapidly disorganizes. Were it not, however, for parallel evidence in a related genus (Widdringtonia), one would be much more inclined to come to the conclusion that no ventral nucleus is normally cut off, as is said to be probably the case in Torreya taxifolia (6). ${ }^{1} \quad$ It is also worth noting that no ventral nucleus was identified in Callitris, which is much more nearly related to Actinostrobus than is Widdringtonia. The series obtained in Callitris was not, however, such a close one as that in Actinostrobus. A possible explanation, which is very frequently overlooked by investigators, of the persistent absence of a certain stage in a particular plant, is that the stage concerned only occurs at certain hours of the day or night, at which collections were not made. ${ }^{2}$ In a recent paper by Lutman (15) on Closterium, it was shown that nuclear and cell division in that genus always occurred at night. I am not aware

1 The case of Torreya taxifolia, however, is emphatically ' not proven'.

2 Since the above was written I see that Burlingame, working on Araucaria (Bot. Gaz., Feb., I9I3, p. 99), suggests a similar explanation of the difficulty experienced in securing certain stages of development. 
whether any investigator of Conifer morphology has ever tested the value of collections made during the night, but it is undeniable that certain stages are repeatedly met with in day collections, while others are extremely rare. The current explanation, that the rare stages are those passed through very quickly, is no doubt true in some cases, but where a single collection includes an approximately equal number of stages before and after the one looked for, which still is persistently absent, it is not unreasonable to infer that it may only occur at a certain time of the day or night other than that at which the collection was made, or at least far more frequently at such a time.

The mature archegonia are always found (in normal prothalli) in lateral groups of about twenty-five to thirty, abutting on the lower part of a pollen-tube, one such group being formed in relation to each pollentube. It is not always quite clear whether the pollen-tube is actually within the tissue of the prothallus, but it is certainly so in many cases, and where not apparent may be due to the crushing of the outer cells. Thus it is probable that archegonia are always deep-seated, and certain that they usually are. Part of a tangential section of a prothallus cutting a single group of archegonia transversely is shown in Fig. 15. The microphotograph reproduced in Pl. XXVIII, Fig. 53 shows a similar section.

The archegonia which may be eventually found in prothalli in which no normal pollen-tubes occur, vary a good deal, but a typical case is shown in Fig. 16, the cells in which contents are drawn being quite sharply differentiated from the rest.

Some other points in connexion with the older ovule and prothallus may now be mentioned, although some are only to be observed subsequently to fertilization.

Alternating with the three wings of the integument are found three large secretory cavities in the tissue, which may be about $3 \mathrm{~mm}$. long, I $\mathrm{mm}$. wide, and $0 . \mathrm{Imm}$. thick. Their position in transverse section is indicated in Fig. I7, and one of them is drawn on a larger scale in Fig. I8. It is very probable that resin is secreted in these cavities, but having only fixed material at my disposal, which has been repeatedly washed in alcohol, it has not been possible to determine this point. It is seen in Fig. I7, and more clearly in Fig. 19, that the nucellus has also three quite rudimentary wings, corresponding in position to those of the integument. The outline of the prothallus in cross-section may be sub-triangular (Fig. 19), almost circular (Fig. I7), or somewhat elliptical (Fig. I6).

The megaspore membrane is, from the first, very thin and inconspicuous, but thickens somewhat in a quite old prothallus. Its thickness when a good-sized embryo has been formed is indicated in Fig. 20, which also shows two of the marginal starch-packed cells. Two cells near the margin, one uninucleate the other binucleate, are shown in Fig. 21. Practically all 
the cells near the middle of the prothallus, and especially those near the advancing embryo, become binucleate or four-nucleate. One such four-nucleate cell is drawn in Fig. 22. A dividing nucleus in a prothallus cell is shown in Fig. 23. The chromosomes are very thick, and it is not possible to show more than about half of them in a drawing. The number passing to each pole is eight. A single dividing nucleus in a prothallus cell is quite commonly met with, but only one case has been seen of two dividing nuclei side by side in the same cell. This, however, serves to establish the fact that the four-nucleate cells are derived from the binucleate by simultaneous mitosis of the two nuclei.

The binucleate and four-nucleate cells are exactly like those of Widdringtonia and Callitris, and it is here necessary to correct a completely inaccurate statement made by Coulter and Chamberlain (5) in reference to this point. They state (p. 262), 'Saxton has observed the same free nuclear division in the primary endosperm cells of Widdringtonia' (primary cells are defined on the same page as 'those open towards the centre of the sac'-i. e. the alveoli), 'but in this case the cells usually become only binucleate (occasionally multinucleate), and this binucleate or multinucleate condition persists in the permanent tissue, as if the last stage of other forms were omitted in Widdringtonia.' Without further comment, I add the following extracts from my own statements in the two papers cited by Coulter and Chamberlain in this connexion: 'A large number of nuclear divisions have been seen in the "alveoli", certain features of which strongly recall the peculiar divisions described by Lawson as occurring at this time in Cryptomeria. The wall between the nuclei, however, is always developed, but in cases where its width does not nearly equal the diameter of the cell, it is just possible that wall and fibres may disappear again, and thus give rise to a binucleate cell. It has not been demonstrated, however, that binucleate cells ever originate in this way' $(20$, p. 35$)$. 'The cells at first formed are invariably uninucleate . . ' $(19$, p. I67). It seems perfectly clear ... that the binucleate (and in some cells multinucleate) condition arises by karyokinetic division of the original single nucleus' $(19$, p. I70).

This bi- and multinucleate condition of older prothallial cells is more widely distributed in the Pinaceae than the literature of the subject would indicate. They are also known to occur in the Taxaceae, having been recorded in Podocarpus (Coker (3) and Gibbs (8)), and Taxus (Jaeger (11)). In Cephalotaxus also, the writer has had the privilege of examining some excellent preparations made by $\mathrm{Mr}$. L. A. Boodle, in which several free nuclear divisions may be seen in a single cell of the prothallus.

From the writer's preparations of other Conifers, and published records, the following facts have been noted: In Araucaria Cookei binucleate, and occasionally four-nucleate, cells seem to be more or less the rule in the 
central part of the prothallus, at the time when the archegonia are mature. Such cells are fairly frequent in Cupressus at a later stage, but very rare in Pinus. I cannot agree with Miss Ferguson (7) that the formation of such cells in Pinus is always delayed to such a late stage as that to which she refers, though undoubtedly the first-formed cells are always uninucleate, as they are in Callitrineae. From the remarks made by Miyake (16) in connexion with Cunninghamia, though he is not very explicit, one concludes that binucleate cells are occasionally found in the older prothallus.

In Sequoia I have not been able to demonstrate such cells at the time when archegonia are about mature, but my preparations are not good enough to say definitely that they are absent. Lawson (14) does not mention the point. To summarize, the phenomenon is by no means confined to the Callitrineae, but is more conspicuous in them than in any other Pinaceae. In the Taxaceae, as far as known, it is much more prevalent, possibly owing in some cases to the small size of the nuclei, as noted in preparations of Podocarpus Thunbergii. ${ }^{1}$ On the whole, there is no evidence that the character is of any importance, except as a nutritive adaptation.

\section{The Male Gametophyte.}

The pollen-grain, as first found in the micropyle, still contains only a single nucleus. The thin exine bursts, and starch is no longer found surrounding the nucleus. In the example figured (Fig. 24) the grain is lodged on the side of the integument, just above the nucellus, but normally the pollen becomes attached to the apex of the nucellus.

The divisions giving rise to the nuclei of the pollen-tube have not been seen, the next figure (25) showing a well-organized body cell, and two small nuclei, exactly alike in size and structure, embedded in a single mass of cytoplasm in advance of the body cell. In this figure one sterile nucleus is in advance of the other, but in later stages, until the body cell divides, they are almost invariably abreast. The tube takes a somewhat sinuous course (Figs. 8 and 25) through the middle of the nucellus, and may occasionally branch quite close to the apex. It has not been observed to branch in the lower (meristematic) part of the nucellus. The number of pollen-tubes growing down the nucellus is commonly two. Their position in a transverse section of the nucellus is shown in Pl.XXVI,Fig. 26. Sometimes three or four pollen-tubes are found. The tubes reach the tip of the embryo-sac long before cell formation begins (Fig. 27), and at once grow into the prothallial cavity. The pollen-tube and its contents take up practically their final position before wall formation begins, though it is probable that a very slight amount of growth may occur later. Shortly before the body cell divides, the tip of the tube has the structure shown

1 Miss Gibbs (8), however, figures a case where the nuclei are very large. 
in Fig. 28. The nucleus of the body cell has increased in size, and its appearance is that of a nucleus about to prepare for division. The cytoplasm is dense and very homogeneous, and the wall is more distinct than in earlier stages. This is the structure of the pollen-tube shortly after wall formation is complete, and Figs. 29 (a transverse section of the pollen-tube and adjacent tissues) and Io show that it is completely embedded in the tissue of the prothallus, and not lying, as is often the case in Widdringtonia, between the megaspore membrane and the prothallial cells. It is quite possible, however, that it does sometimes lie on the outside of the prothallus.

Since some collections included pollen-tubes both before and after division of the body cell, efforts were made to secure stages of this division, but entirely without success, although every stage in the rounding off of the male cells has been seen in numerous preparations, and many others show a body cell like that of Fig. 28. It is, of course, impossible to state precisely the period elapsing between the various stages seen of the rounding off of the male cells, but the short time which elapses between their formation and the occurrence of fertilization makes it likely that these would differ, in time, by only a very few hours. Other investigators have evidently also had difficulty in securing this division, it having only been recorded in comparatively few genera, the latest of these being Funiperus communis, var. depressa, where Nichols (17) figures a few stages of the division, but confesses to failure in the endeavour to obtain a complete series. As he gives a résumé of the work previously done on the same division in other genera, it is not necessary to say more on that score, but taking into consideration the various researches of recent years, and the fact that all investigators collect at short intervals round about the time of fertilization, shortly before which the body cell divides, the conclusion seems inevitable that the body cell much more frequently divides at an hour (doubtless in the night) when collections are seldom or never made, than at any other time. The alternative view would be that the whole division is passed through in an exceedingly short space of time.

As first seen after their formation (Fig. 30) the two male cells appear to be still enclosed in the mother-cell wall. This is a stage which has apparently not been noted previously, it having been assumed that the male cells are not formed within a mother-cell wall. Coulter (4), however, remarked in this connexion, 'it is not an unreasonable expectation that some of the male cells may be found to be formed within mother-cells.' No trace of the mother-cell wall can be seen at a slightly later stage.

Whether the body cell moves down at about the time of its division, or whether the sterile nuclei move up, cannot be positively determined, but from the fact that the end of the pollen-tube is some way below the male cells, the second alternative seems probable. In any event, the two sterile 
nuclei are now found beside the lower male cell as shown in Figs. $30,3^{1}$, and I2. Soon after the stage of Fig. 30, the two sterile nuclei begin to disorganize. The male cells at the same time become hemispherical, and then gradually separate from one another and round out, eventually becoming almost egg-shaped (Fig. 3I). The two male cells are always exactly one above the other in the tube. Occasionally the disorganized remains of the sterile nuclei may be found in the same tube with mature male cells, as shown in the figure, but more often no trace of them is left. That this stage is one very shortly before fertilization is indicated by the fact that another pollen-tube closely adjacent to the one figured was already empty, having fertilized two archegonia in contact with it. In Fig. Io each of the two pollen-tubes shows one of its two male cells cut transversely.

It is necessary here to correct another misstatement in Coulter and Chamberlain's 'Morphology of Gymnosperms': they assert, in regard to Widdringtonia, that 'the single pollen-tube penetrates the megaspore membrane, and ... only after entering within the membrane does the generative cell divide', but the latter statement can only be attributed to a vivid imagination on the part of those authors, as, from the context, it is fairly clear that 'generative cell' was not written merely by a slip of the pen for 'body cell'. It is obvious from the description, and Figs. I7, 30, $3^{\mathrm{I}}$, and $3^{2}$, in my paper on the genus (20), to which reference is made, that the body cell has been formed long before the tube reaches the megaspore membrane, and that the only division which occurs after entering within the membrane is that of the body cell.

At about this time it is noticeable that a good many ovules become abortive, and it seems clear that this is due in all cases to the pollen-tube failing to reach its normal position. It is sometimes found that the tubes never get beyond the nucellus; in other cases they penetrate a little way into the prothallus, but not to the region of archegonium initials. As many as four tubes, extending various distances down the ovule, have been found in one series of sections, all showing the rather undersized body cell characteristic of abortive tubes. Apparently the body cell never divides in these abortive tubes.

It is very rarely that any other abnormality is met with in a pollentube, but the case shown in Fig. 32 is of some interest. Reference has already been made to this tube as the one found in the same prothallus as that in which the archegonia of Figs. I 3 and I 4 were contained. It includes four nuclei and a good deal of cytoplasm. The lowest nucleus is slightly larger than the other three, while the latter are very close to one another in a common mass of cytoplasm. No other nuclei are present in the tube. It may be seen that the size and organization of these nuclei are very much the same as those of normal male cells. (All the later stages of the pollentube are drawn to the same scale.) The likely explanation seems to be 
that all four nuclei (two male cells and two sterile nuclei) were embedded in a common mass of cytoplasm, which did not, therefore, become organized into definite cells around the two male nuclei only, but remained diffuse in the tube. Since all four nuclei were exposed to the same nutritive conditions, they all developed to an approximately equal size. The lowest nucleus, being in contact with the larger bulk of the cytoplasm, has, however, grown a little larger than the rest. It is probable, as noted above, that the archegonia associated with this tube were slightly abnormal, though not markedly so.

\section{Fertilization and Embryogeny.}

Since the details of proembryo formation were not satisfactorily elucidated in either Widdringtonia or Callitris, attention has been somewhat concentrated on this phase of the life-history in Actinostrobus, and all the points of chief importance have been satisfactorily made out.

Certain points were definitely ascertained in regard to the development of the proembryo of Widdringtonia, which Coulter and Chamberlain (5) have incorrectly amplified. They say: 'Saxton states, furthermore, that walls appear in the proembryo of Widdringtonia before the eight-nucleate stage, which probably means that they appear during the transition from the four-nucleate to the eight-nucleate stage, as in most Pinaceae.' In the paper (20) to which reference is there made, a figure was given, described in the text, of a proembryo containing five resting nuclei, between which walls had already been laid down. If Coulter and Chamberlain wish to ignore the conclusions to which investigated facts have led the investigators, they should at least be very careful not to misstate the facts.

Assuming, as is at least reasonably probable, that Callitris and Widdringtonia agree with one another in the main points of their proembryo development, the following are the facts known in regard to fertilization and embryogeny in those genera: (I) The male and female nuclei at the time of fertilization are equal in size and similar in structure. (2) The first division of the fusion nucleus results in the formation of two free nuclei. (3) Walls are formed while there are still less than eight nuclei in the proembryo. (4) Subsequent divisions result in a mature proembryo of about a dozen cells or less, which completely fills the archegonium. (5) In Callitris at least, perhaps not in Widdringtonia, groups of two or three cells probably separate from one another, and in each group the lowest cell (in regard to the apex of the prothallus, not to the apex of the archegonium) gives rise to the embryo, and the cell next above it to the suspensor.

There is now presented a fairly complete account of the corresponding phases in Actinostrobus.

Fertilization has been seen in a considerable number of preparations, 
and, with one or two exceptions, both male cells have proved to be functional. They always fertilize two archegonia which are either adjacent or separated by one unfertilized archegonium, one of them being vertically above the other as regards the long axis of the prothallus.

After fertilization the numerous unfertilized archegonia quickly degenerate, and evidently function as a nutritive tissue, taking the place, in this respect, of the jacket cells commonly present in other Conifers, but which are quite absent here.

The male and female nuclei are of approximately equal size and similar structure, both immediately before and during fertilization, as shown in Figs. 33, 34, and $34 a$. As far as the sexual nuclei are concerned, each of these figures is typical of a number of preparations, but in other respects each shows an interesting abnormality. Reference has already been made to Fig. 33 as the only case seen of a ventral canal cell. No such structure has been seen in other preparations; also the two neck cells are intact, and the male nucleus has evidently penetrated the archegonium from the side.

Fig. 34 is the only case noted where the second male nucleus was definitely identified in a degenerate condition left behind in the tube. The body shown at the apex of the archegonium appeared to be the collapsed remains of the cytoplasm of the functional male cell, but this is not certain, and in other cases it is clear that the cytoplasm passes into the archegonium, as well as the male nucleus, at the time of fertilization. The exceptional case figured is, however, interesting in comparison with the same stage in Sequoia (Lawson (14)), where the cytoplasm is normally left behind in the tube.

Fig. 35 is about the same stage of fusion as Fig. 34, but is the only case noted showing a clear difference in size between the male and female nuclei.

The two sexual nuclei may almost always be seen to be surrounded by a starch sheath. Its origin is obscure, as no starch is visible in either the mature male cell or the mature archegonium. Its appearance in later stages is rather sporadic; speaking generally, it is not seen in connexion with any nuclei in mitosis, except early in the first division, but reappears after the daughter nuclei are fully organized. It has practically disappeared by the time the proembryo is mature, and is never seen after the suspensor begins to elongate.

To make the following description clear, the terms 'apex' and 'base' and 'long axis' will refer to the archegonium and not to the prothallus. Since the long axis of the archegonium is at right angles to that of the prothallus, the need for such a distinction is obvious.

In the first division, the spindle (Fig. $3^{6}$ ) is seen to be entirely intranuclear, as usual, and the poles are rather broad. The stage figured is 
evidently before the splitting of the chromosomes, and sixteen can be counted on the equator of the spindle (Fig. $36 \alpha$ ). At this time no segregation of the chromosomes into two groups (representing $\sigma^{7}$ and $q$ ) could be seen, but this would hardly be expected except at an earlier stage of division.

The spindle may be oblique to the long axis (Fig. 36) or parallel to it (Pl. XXVII, Fig. 37). It may be that it starts parallel to the plane of fusion of the maternal and paternal nuclei, and subsequently becomes parallel to the long axis, but the number of preparations of these stages is not sufficient to substantiate the suggestion. Fig. 37 shows the two daughter nuclei reorganizing, with the spindle still quite evident between them. No cell-plate is laid down and the spindle disappears completely.

The basal nucleus next divides to form two daughter nuclei, placed one above the other, or somewhat obliquely (Figs. $3^{8}$ and 39), and is very quickly followed by the upper nucleus, which divides in a transverse plane. We have thus the arrangement represented in longitudinal section in Fig. 40, in which it is most clearly shown that cell-plates have been formed from the spindles, traces of which can still be seen between the pairs of daughter nuclei. The segmentation is then completed by the formation of a cleavage plane between the two pairs of daughter nuclei, giving the arrangement shown in Fig. 4I.

The later stages are sometimes difficult to interpret, because it is often impossible to say whether a group of embryonic cells is formed from one fertilized archegonium, or from two adjacent archegonia, the wall between adjacent archegonia being exactly like that between adjacent proembryo cells. In any case, it is certain that some cell divisions follow the stage of Fig. 4I, probably only occurring in the two basal cells, but it is unlikely that their sequence or number is constant. Parts of proembryos are shown in section in Figs. 42 and 43 , in which the divisions in progress are probably the last which occur in the formation of the mature proembryo.

The mitotic figures of Fig. 42, from both the sections in which they are seen, are drawn on a larger scale in Figs. $42 a$ and $42 b$. The stage of division is slightly later than that shown in Pl. XXVI, Fig. $3^{6}$, after the splitting of the chromosomes, and thirty-two chromosomes, i. e. sixteen for each daughter nucleus, can be counted in each mitosis.

Each cell of the mature proembryo, except the two apical cells, which appear to take no further part in the development, gives rise by a mitotic division to two cells of very unequal size, the larger of which becomes the suspensor, and the smaller the embryo initial. This mitosis always occurs towards that side of the cell nearest the basal end of the prothallus (Figs. 44 and 4.5). In this division the sporophytic number of chromosomes (I6) has again been counted (Fig. $45 a$ ). The two resulting cells (suspensor and embryo initial) are shown very shortly after their formation in Fig. 46, and somewhat later in Fig. 47, when the difference in size of the 
nuclei is more pronounced. A few starch grains are seen in the suspensor in this figure, but are seldom found at such a late stage.

After this the suspensors rapidly elongate and their walls thicken, and they form an intertwining mass of long tubes in the region previously occupied by the disorganizing, unfertilized archegonia, eventually breaking down nearly all the apical tissue of the prothallus (PI. XXVIII, Fig. 54).

The large nucleus of the suspensor is very persistent, as well as conspicuous, and may be identified for quite a long time in the development of
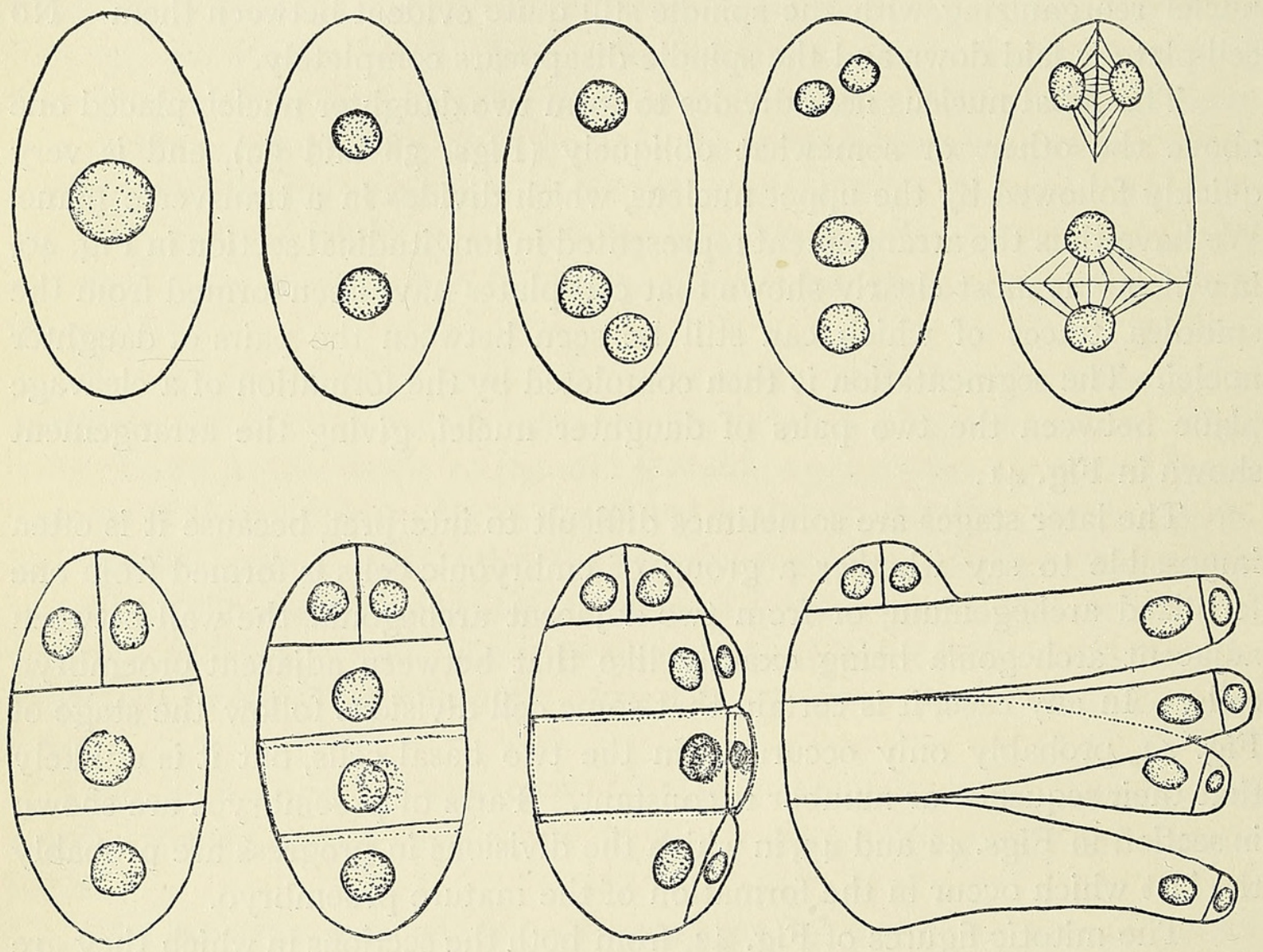

TEXT-FIG. 3. Series of diagrams to illustrate the development of the proembryo, formation of embryo cells, and elongation of the suspensors. $x$ about 350 . (The apex of the prothallus is supposed to be to the left, in these diagrams.)

the embryo. It remains near the embryo, embedded in a small mass of cytoplasm, the rest of the suspensor being devoid of contents.

A group of four suspensors and embryo initials is shown in Fig. 48, shortly after the suspensors have begun to elongate, and two at a later stage in Fig. 49; a somewhat similar group is shown in the microphotograph (Fig. 54).

The embryo initials remain undivided for a considerable time, something like ten days or a fortnight, and the first division wall is vertical, as shown in Figs. 50 and 55 (microphotograph), this being quickly followed by 
a second vertical wall in each of the resulting cells, in a plane at right angles to the first. There is thus formed a single tier of four cells at the tip of the suspensor. The next division is transverse (Fig. $5 \mathrm{I}$ ). The subsequent development has not been followed closely, but scattered stages, such as those shown in Figs. 52 and 56 (microphotograph), indicate that the later stages are very similar to those of Pinus and other Conifers. Embryonal tubes are a conspicuous feature, as in many other Conifers, and are well shown in Fig. 56. It is perhaps worth noting that the four cells formed by the first divisions in the embryo initial always remain associated, constituting a single embryo.

The number of cotyledons in the mature embryo is always two, as noted by Hill and de Fraine (10), and in spite of the large number of embryos which begin to develop, no case of more than one embryo reaching an advanced stage has been observed. The development of the proembryo, and the differentiation of suspensors and embryo initials, are indicated in the series of diagrams in Text-fig. 3 .

\section{Conclusions.}

The chief result of the present study has been the more detailed knowledge now obtained of the proembryo and embryo development, which has emphasized the conclusion previously reached $(20,21)$, that these stages in the Callitrineae are radically different from the corresponding stages in all other Conifers. There can be no doubt that the proembryo development is substantially the same in Callitris and Actinostrobus, and to a less extent in Widdringtonia also.

The close resemblance between Actinostrobus and Callitris in almost every respect is very remarkable, and tends to emphasize the differences between these Australasian genera on the one hand, and the African genus of the Callitrineae, Widdringtonia, on the other.

In previous studies the opinion has been expressed, both by the present writer and by others who have investigated those Conifers with lateral archegonia, that this (i. e. lateral position of archegonia) is probably an 'ancient' character. The evidence was perhaps mainly the fact that they were associated with many other 'ancient' characters in the Araucarians; in any case, the evidence was not complete, and Coulter (4) has justly criticized the view, and stated sound arguments for an opposite opinion. Land (13) and Pearson (18) had previously taken the position that this tendency might represent an advance towards Gnetoid conditions. Further study of the Callitrineae has tended to show that Coulter's view is likely to be the right one, and some further evidence has been recently brought forward in this direction by the writer (22) from an abnormal Pine prothallus with only lateral archegonia, although opinion will doubtless differ 
as to its value. The present conclusions, based largely on the study of Actinostrobus, supplemented by published work on other Conifers with lateral archegonia, are as follows: (I) The occurrence of prothalli with lateral archegonia, in Conifers, is regarded as a 'mutation' from the usual type of prothallus. (2) The production of a prothallus with lateral archegonia probably occurred at least twice in the phylogeny of the group : $(a)$ When the Araucarians were differentiated from the Abietineae, which may be regarded as having taken place quite early in the history of Conifers, soon after differentiation from the Cordaitales. In the Abietineae the somewhat widely separated archegonia of the Cordaitales, as figured in Cycadinocarpus (Coulter and Chamberlain after Renault (5)), approximated more closely, while in the Araucarians they separated more widely. In preparations of Araucaria Cookei and A. excelsa the writer has found the archegonia to lie, with their apices pointing obliquely outwards, very slightly below the rather flattened apex of the prothallus. Each archegonium has its own layer of well-defined jacket cells, and a rather large number of neck cells, which lie at the bottom of a canal very similar to that leading to each archegonium in Pinus. It is stated (Seward and Ford (23)), that the archegonia may be deep-seated in some cases, but more work is needed on the genus before such a statement can be definitely accepted; it is not even clear whether 'deep-seated' in this connexion may not mean, merely, sunken at the base of a canal, as in Pinus. (b) When the Cupressineae, Callitrineae, and Sequoiineae materialized: doubtless a later event than the Araucarian differentiation. The close resemblance, in many respects besides the lateral archegonia, between Sequoia and the Callitrineae has already been emphasized, and the conclusion seems justified that the two tribes were derived from a common ancestry with lateral archegonia, while the Cupressineae developed and retained the apical group with a common jacket layer. Where any trace of a jacket layer does occur in Callitrineae, it also surrounds a group of archegonia as a rule, and not individual archegonia. More often specialized jacket cells do not become differentiated at all.

As regards other relationships, it has been suggested before that of all Conifers the Callitrineae come nearest to the Gnetales. The formation of the embryo and suspensor from a single proembryonal cell is by no means dissimilar to what occurs in Ephedra (Land (13)) and Welwitschia (Pearson (18)), though the formation of a cleavage plane instead of a cellplate is admittedly an important difference. The first three series of divisions in the embryo are also identical with those in Welwitschia (Pearson (18)). Coulter (4), although regarding any attempt to select the tribe of Conifers most nearly related to the Gnetales as 'peculiarly unprofitable', nevertheless implies on a later page that his own selection is the Cupressineae. Doubtless he is quite justified in saying that any such 
connexion may mean only the parallel development of the two groups; it very probably does; but it seems of interest to note a likelihood that in certain respects the Callitrineae have perhaps developed in a similar direction to the Gnetales, and that to a somewhat less extent the Cupressineae have also done so.

The general question of Conifer classification is to be discussed in another place, and no further reference need be made to it here.

\section{Summary.}

I. About three months elapse between pollination and fertilization in Actinostrobus.

2. Each microsporophyll bears usually three sporangia.

3. The mature pollen-grains are uninucleate.

4. From six to twelve (usually nine) ovules are borne in each female cone.

5. A single megaspore mother-cell is formed in the nucellus, and no spongy tissue is organized.

6. Archegonia are formed from the alveoli, after the cutting off of some small cells at base and apex, and are deep-seated, a group of twenty-five to thirty being found abutting on the lower end of each pollen-tube, which reaches about half-way down the prothallus.

7. Large secretory cavities are found in the tissue of the integument, alternating with the wings.

8. The older cells of the prothallus are generally binucleate or fournucleate.

9. The male gametophyte agrees very closely with that of Cupressineae, but the two male cells appear to be enclosed within a mother-cell wall when first formed.

I0. The two male cells fertilize two approximately adjacent archegonia. structure.

II. In fertilization the sexual nuclei are practically alike in size and

I2. Wall formation in the proembryo occurs during, and following, the transition from the binucleate to the four-nucleate condition (i. e. earlier than in most Pinaceae), and the proembryo completely fills the archegonium.

I3. Most of the cells of the mature proembryo give rise, by a very unequal division, to a suspensor and an embryo initial.

14. The first two division walls in the embryo initial are vertical. Conifers.

15. Further development of the embryo is the same as in other 
I6. The haploid and diploid numbers of chromosomes are eight and sixteen, respectively.

I7. The occurrence of lateral archegonia in Conifers is regarded as a specialized condition, which probably arose independently at least twice in the history of the group.

\section{LITERATURE CITED.}

1. Baker, R. T., and Smith, H. G. : A Research on the Pines of Australia. Sydney, Igio.

2. Bower, F. O.: Studies in the Morphology of Spore-producing Members. I 894-1903.

3. Coker, W. C.: Notes on the Gametophytes and Embryo of Podocarpus. Bot. Gazette, vol. xxxiii, I902, pp. 89-I07, Pls. v-vii.

4. Coulter, J. M.: Evolutionary Tendencies among Gymnosperms. Bot. Gazette, vol. xlviii, 1909, pp. 8I-97.

5. Chicago Press, Chicago, I9Io.

6 and LAND, W. J. G. : Gametophytes and Embryo of Torreya taxifolia. Bot. Gazette, vol. xxxix, I905, pp. 16I-1 78, Pls. A, i-iii.

7. Ferguson, M. C. : Contributions to the Life-history of Pinus, with Special Reference to Sporogenesis, the Development of the Gametophytes, and Fertilization. Proc. Wash. Acad. Sci., vol. vi, 1904, pp. I-102, Pls. i-xxiv.

8. Gibbs, L. S.: On the Development of the Female Strobilus in Podocarpus. Ann. Bot., vol. xxvi, I9I 2, pp. 5I5-7I, Pls. xlix-liii.

9. Goebel, K.: Outlines of Classification and Special Morphology. English translation, I887.

10. Hill, T. G., and DE Fraine, E.; On the Seedling Structure of Gymnosperms. I. Ann. Bot., vol. xxii, I908, pp. 689-7 I $2, \mathrm{Pl}$. xxxv.

11. JAEGER, L. : Beiträge zur Kenntniss der Endospermbildung und zur Embryologie von Taxus baccata. Flora, vol. 1xxxvi, I899, pp. 24I-88, Pls. xv-xix.

12. Juel, H. O.: Ueber den Pollenschlauch von Cupressus. Flora, vol. xciii, 1904, pp. 56-62, Pl. iii.

13. LAND, W. J. G. : Fertilization and Embryogeny in Ephedra trifurca. Bot. Gazette, vol. xliv, I907, pp. 273-92, Pls. xx-xxii.

14. Lawson, A. A.: The Gametophyte, Archegonia, Fertilization, and Embryo of Sequoia sempervirens. Ann. Bot., vol. xviii, I904, pp. I-28, Pls. i-iv.

15. Lutman, B. F.: Cell and Nuclear Division in Closterium. Bot. Gazette, vol. li, I9I I, pp. 40I-30, Pls. xxii, xxiii.

16. MiYAKe, K.: The Development of the Gametophytes and Embryogeny of Cunninghamia sinensis. Beih. Bot. Centralbl., xxvii, I9I I, pp. I-25, Pls. i-v.

17. Nichols, G. E. : A Morphological Study of Funiperus communis, var. depressa. Beih. Bot. Centralbl., vol. xxv, I9IO, pp. 20I-4I, Pls. viii-xvii.

18. Pearson, H. H. W.: Further Observations on Welwitschia. Phil. Trans. Roy. Soc. London, $\mathrm{B}$, vol. cc, I909, pp. 33I-402, Pls. xxii-xxx.

19. Saxton, W. T.: Preliminary Account of the Development of the Ovule, Gametophytes, and Embryo of Widdringtonia cupressoides, Endl. Bot. Gazette, vol. xlviii, 1909, pp. 16I-78, Pl. xi.

20. : Contributions to the Life-history of Widdringtonia cupressoides. Bot. Gazette, vol. 1, I910, pp. 31-48, Pls. i-iii. 
21. Saxton, W. T. : Contributions to the Life-history of Callitris. Ann. Bot. xxiv, I910, pp. $557-69$, Pls. xlv, xlvi.

22. $\quad$ : Note on an Abnormal Prothallus of Pinus maritima, L. Ann. Bot., vol. xxvi, I9I 2 , pp. 943-5.

23. Seward, A. C., and Ford, S. O.: The Araucarieae, recent and extinct. Phil. Trans. Roy. Soc., London, B, vol. cxcviii, 1906, pp. 305-4II, Pls. xxiii, xxiv.

\section{EXPLANATION OF FIGURES IN PLATES XXV-XXVIII.}

\section{Illustrating Mr. Saxton's paper on Actinostrobus.}

Note. All figures of longitudinal sections are oriented with the longer axis of the ovule vertical and the micropylar end upwards, except Figs. $36-43$, which are with the longer axis of the ovule horizontal (approximately) and that of the archegonium vertical, with the apex of the archegonium upwards. The orientation of Figs. $53^{-56}$ (Plate XXVIII) is indicated by an arrow.

In all : $a=$ archegonium ; $b=$ body cell $; c=$ micropyle closing cells, $d=$ megaspore mother cell; $e=$ embryo cell ; $f=$ neck cells; $g=$ secretory cavity; $h=$ sterile nuclei of the pollentube ; $i=$ integument ; $k=$ embryonal tubes (secondary suspensors); $m=$ male cells; $n=$ nucellus; $p=$ prothallus; $s=$ suspensor ; $t=$ pollen-tube; $v$. = ventral nucleus; $\delta=$ male nucleus ; $\uparrow=$ female nucleus.

\section{PLATE XXV.}

Fig. I. Transverse section through the stalk of the microsporophyll. $\times 80$.

Fig. 2. Section of a mature pollen-grain. $\times$ I, I00. July I3.

Fig. 3. Longitudinal section of a young ovule, before pollination. $\quad \times$ I 20.

Fig. 4. Young megaspore mother-cell, in longitudinal section. $\times 55^{\circ}$. June $\mathbf{I}$.

Fig. 5. Megaspore mother-cell in synapsis. $\times 95^{\circ}$. June $\mathrm{I}$.

Fig. 6. Megaspore with remains of non-functional megaspores. $\times 95^{\circ}$.

Fig. 7. Binucleate megaspore. $\times 800$. July I 3.

Fig. 8. Longitudinal section of a whole ovule at the time when the young embryo-sac contains eight nuclei. $\times$ I60. July $\mathrm{I} 3$.

Fig. 9. Part of the prothallus in longitudinal section at the time when cell formation is taking place. $\times 200$. Oct. I 2 .

Fig. I0. Transverse section of prothallus, showing position of young archegonia and pollentubes. $\times 200$. Oct. $\mathrm{I} 2$.

Fig. II. Transverse section of the neck of an archegonium. $\times 340$.

Fig. I2. Longitudinal section of part of a prothallus, showing three archegonia and the contents of a pollen-tube. $\times 340$. Oct. I9.

Fig. I3. Only case seen of an archegonium showing a ventral canal nucleus. (See text.) $\times 485$. Oct. I 4 .

Fig. I4. Abnormal archegonium. (See text.) $\times 45^{\circ}$. Oct. I4.

Fig. I 5. Tangential section of part of a prothallus, cutting a single group of archegonia transversely. $\times$ I 90 . Oct. $\mathbf{2} 2$.

Fig. I6. Transverse section of a prothallus, in which no pollen-tube was found, showing very deep-seated archegonia. $\times$ 100. Oct. $\mathbf{1} 2$.

Fig. I 7. Transverse section of an ovule, showing the structure of the integument. $\times$ I $_{5}$.

Fig. 18. Part of the same section, showing one of the secretory cavities on a larger scale. $\times 50$.

Fig. 19. Transverse section of a nucellus and prothallus. $\times 24$. $\times 650$.

Fig. 20. Two cells at the margin of a fairly old prothallus, showing the megaspore membrane.

Fig. 21. Two cells near the margin of the same prothallus as Fig. $26 . \quad \times 650$.

Fig. 22. Prothallus cell with four nuclei. $\times 500$. 
Fig. 23. Dividing nucleus in a prothallus cell. $\times 860$.

Fig. 24. Pollen-grain in the micropyle of the ovule. $\times 950$.

Fig. 25. Young pollen-tube in the apex of the nucellus. $\times$ 200. Aug. 23.

\section{PLATE XXVI.}

Fig. 26. Transverse section of nucellus showing two pollen-tubes. $\times$ I 20.

Fig. 27. Tip of a pollen-tube which is just passing into the prothallus, some time before cell formation begins. The megaspore membrane had not been penetrated at this time, and had somewhat contracted. It therefore does not appear in the figure. $\times 360$. Sept. I 2.

Fig. 28. The tip of the pollen-tube very shortly before the body cell divides. It is now far down in the prothallus. $\times 360$. Oct. 4 .

Fig. 29. Transverse section of a pollen-tube and surrounding tissue of the prothallus and nucellus, to the outside of the latter. $\times 200$.

Fig. 30. The contents of a pollen-tube very shortly after the formation of the two male cells. The latter are seen to be still enclosed in a delicate mother-cell wall. $\times 360$. Oct. 4 .

Fig. 31. Contents of a mature pollen-tube, just before fertilization. $\times 360$. Oct. I 2 .

Fig. 32. Tip of an abnormal pollen-tube. $\times 360$. Oct. 4 .

Fig. 33. Archegonium showing the male and female nuclei in contact. A ventral canal cell is shown, which is certainly not a normal feature of the archegonium. $\quad \times 775$. Oct. 9 .

Fig. 34. Archegonium and part of pollen-tube. The male and female nuclei are fusing, and the cytoplasm of the functional male cell, together with the second male cell, is left behind in the tube. $\times 205$. Oct. 9 .

Fig. $34 a$. The fusing nuclei and starch sheath of Fig. 34. $\times 775$.

Fig. 35. Similar to Fig. 34 a, but showing a distinct difference in size between the two nuclei. $\times$ 775. Oct. 9 .

Fig. 36 . Archegonium showing the first division of the fusion nucleus. $\times 485$. Oct. 9 .

Fig. $36 a$. Part of Fig. 36 on a larger scale. $\times 830$.

\section{PLATE XXVII.}

Fig. 37. A later stage than Fig. 36. The daughter nuclei reorganizing. No cell plate is being formed. $\times 830$. Oct. 9 .

Fig. $3^{8}$. The division of the lower daughter nucleus. A cell plate is being formed between the grand-daughter nuclei. $\times$ 700. Oct. I 2.

Fig. 39. A later stage, after the wall is complete. $\times 485$. Oct. 12.

Fig. 40. Stage between Figs. 38 and 39, showing cell-plates practically complete between both pairs of grand-daughter nuclei. $\times 485$. Oct. 9 .

Fig. 4I. Later stage showing wall formation complete in the proembryo. One of the neck cells is still visible. $\times 4^{8} 5$.

Fig. 42. Section showing some of the later divisions in proembryo cells. The upper cell is one of the two upper cells corresponding to those of Figs. 40 and 4 I. $\times 4^{8} 5$. Oct. I 2.

Figs. $4^{2} a$ and $4^{2} b$. Parts of the dividing nuclei of Fig. $4^{2}$, drawn on a larger scale, from each of the two sections in which they are seen. $\times 830$.

Fig. 43. A similar section to Fig. $42 . \times 485$. Oct. I 2 .

Fig. 44. Mitosis in a mature proembryo cell, cutting off an embryo cell from a suspensor. $\times 485$. Oct. I 2 . Oct. I 2 .

Fig. 45. A slightly later stage than Fig. 44, showing the formation of a cell plate. $\times 485$.

Fig. 45 a. Part of Fig. 45 on a larger scale. Sixteen chromosomes may be counted at each pole. $\times 830$.

Fig. 46. Suspensor and embryo cell, shortly after the division is complete. $\times 485$. Oct. I 2.

Fig. 47. A slightly later stage than Fig. 46. The suspensor is just beginning to elongate. $\times$ 830. Oct. I 2 .

Fig. 48. A group of four suspensors and embryo cells, at a later stage. Only the ends of the suspensors are shown in the section. One binucleate prothallus cell has been drawn; the other surrounding prothallus cells are not shown. $\times 360$. Oct. 12. 


\section{Actinostrobus pyramidalis, Miq.}

Fig. 49. Two suspensors and embryo cells at a later stage, when the embryo cell has enlarged preparatory to its first division. $\times 360$. Oct. I2.

Fig. 50. End of suspensor and embryo, after the formation of the first (vertical) division wall. $\times 485$. Nov. I.

Fig. 5I. Transverse division in one of the four cells of the first-formed tier. No wall could be certainly identified between the two nuclei, but doubtless it would be visible at a slightly later stage. $\times 485$. Nov. I.

Fig. 52. A much later stage, showing the formation of embryonal tubes from the embryo cells next to the suspensor. The suspensor nucleus is still quite conspicuous at this time. $\times 205$. Nov. II.

\section{PLATE XXVIII.}

Fig. 53. Microphotograph of a similar section to Fig. I $5 . ~ \times \mathrm{I}_{5} \mathrm{O}$. Oct. 9.

Fig. 54. Microphotograph showing a group of suspensors and embryos, about the same age as Fig. 49. The multinucleate prothallus cells can also be seen. $\quad \times$ I 50. Oct. 14.

Fig. 55. Microphotograph of a similar stage to Fig. $50 . \times 45^{\circ}$. Nov. I.

Fig. 56. Microphotograph of a later stage than Fig. 52. The embryonal tubes are now very conspicuous. $\times \mathrm{I}_{5} \mathrm{O}$. Nov. $2 \mathrm{I}$. 


\section{Annals of Botany}

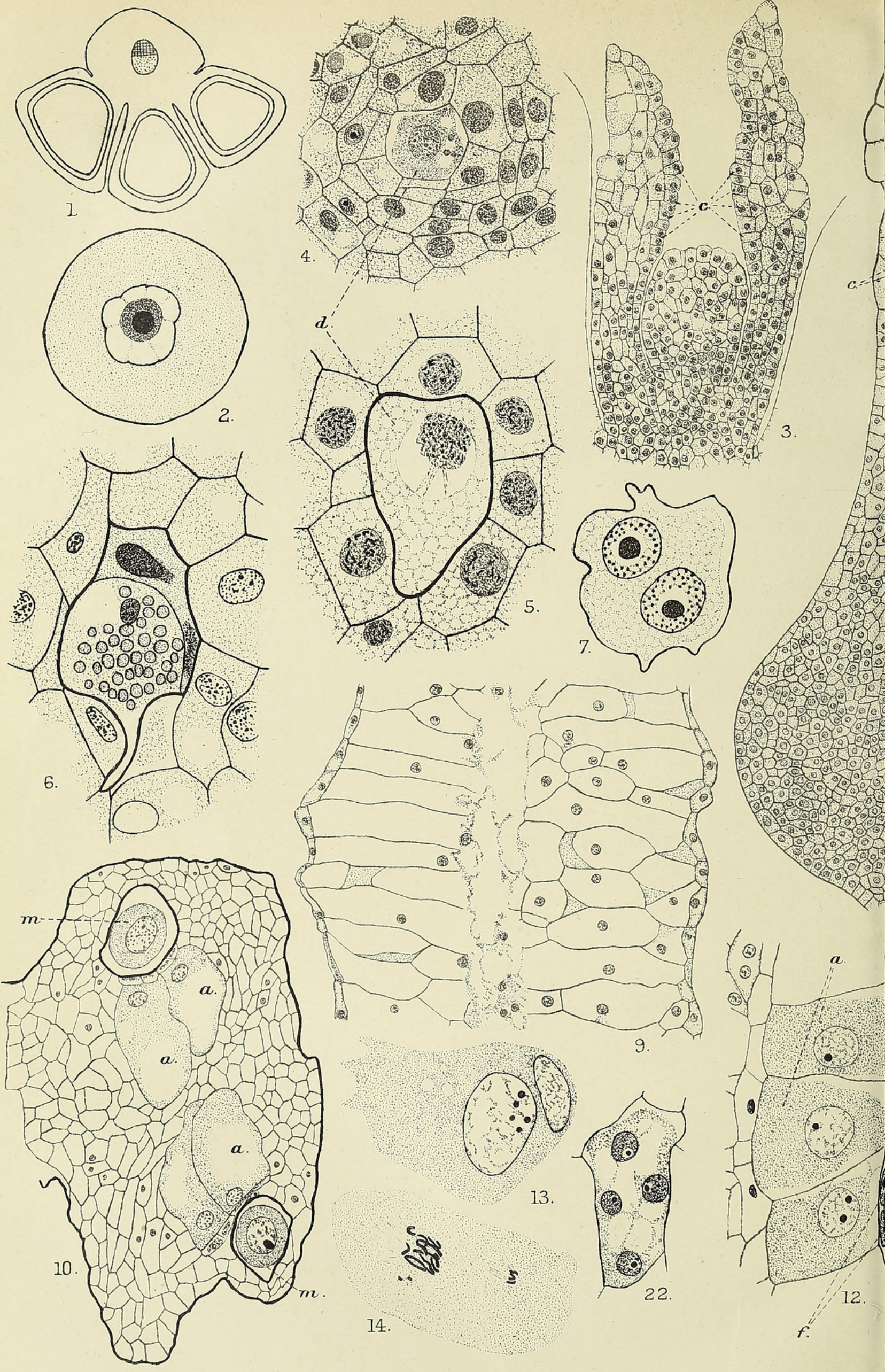

W.T.Saxt on del 


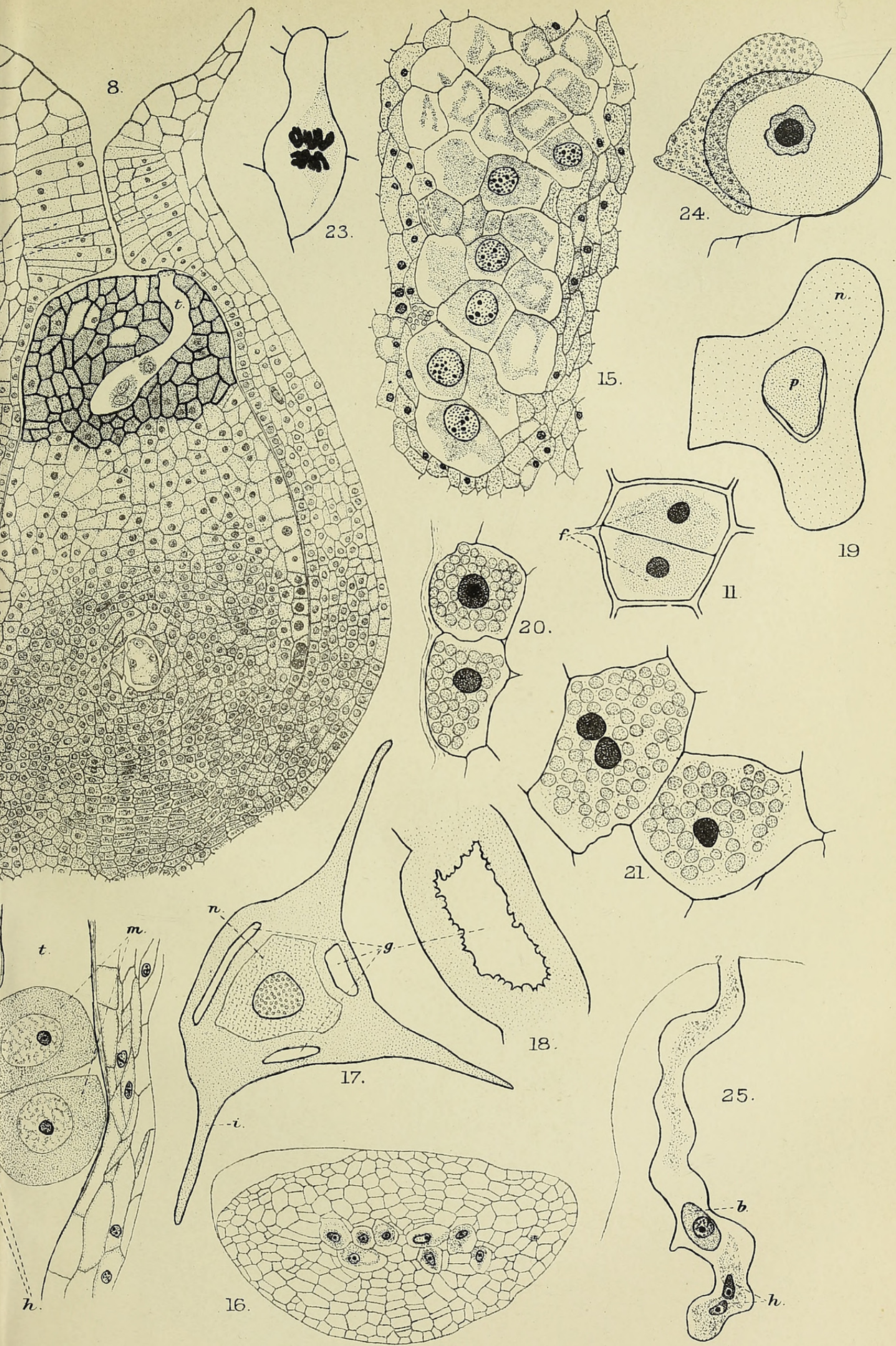




\section{Annals of Botany}
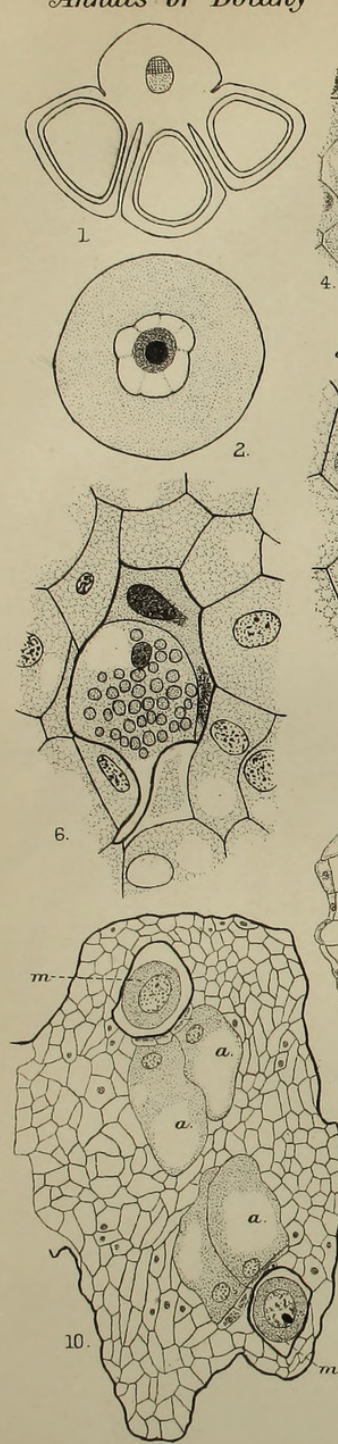

W.T.Saxton del
$10 \times 10$ 160

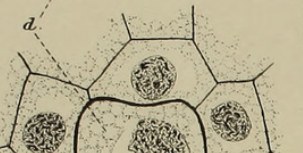
3), 0.0. 64) $5=0$ 4. 23.10
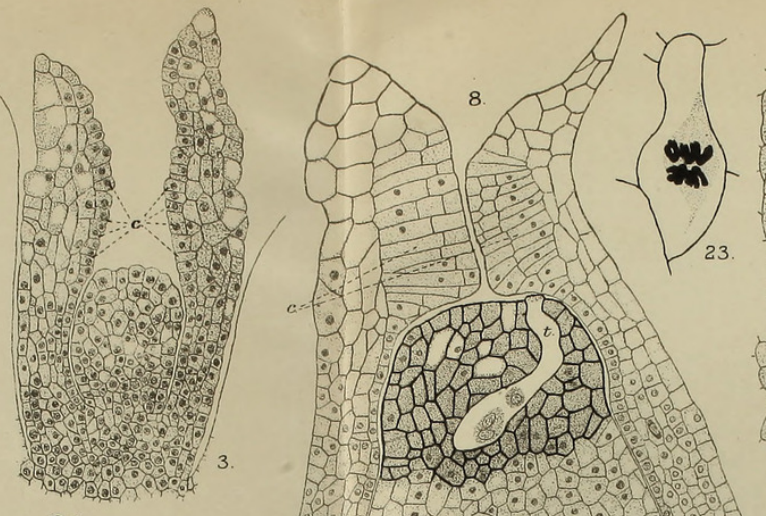

2.2.
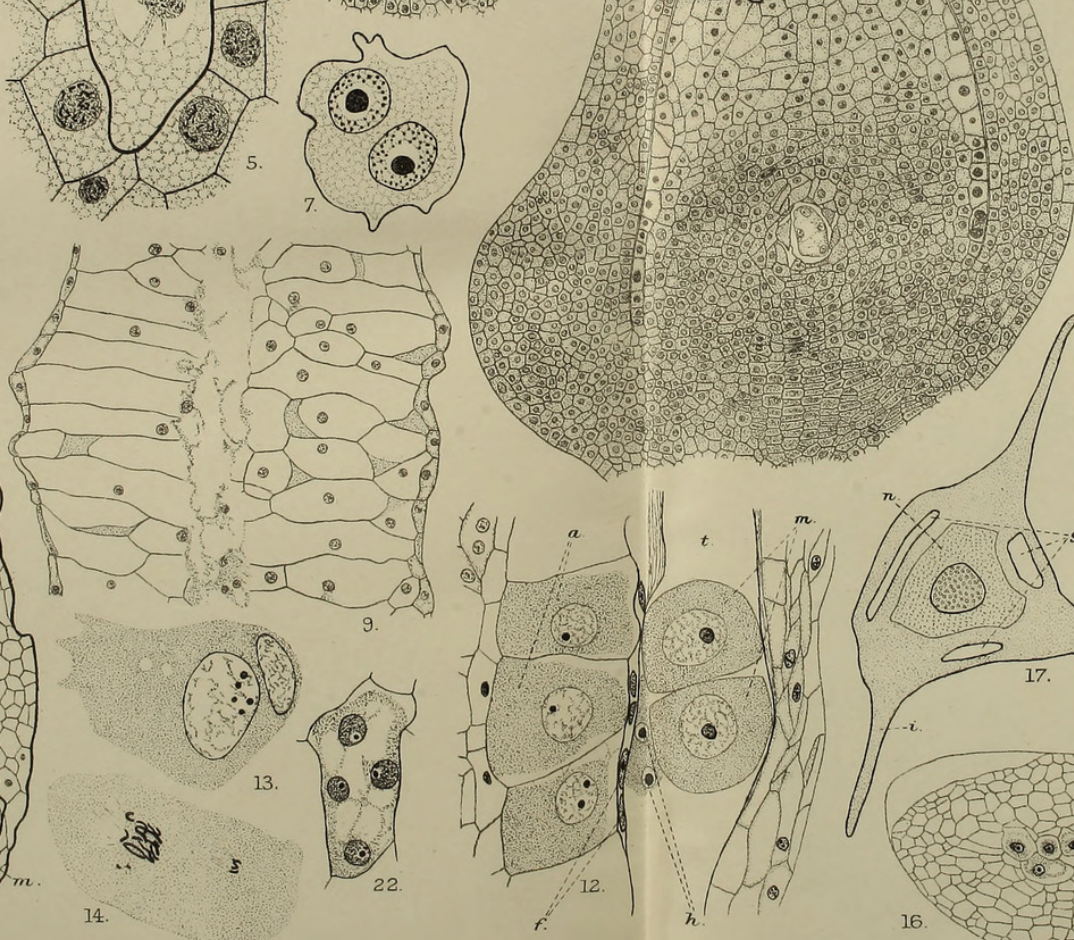

14.
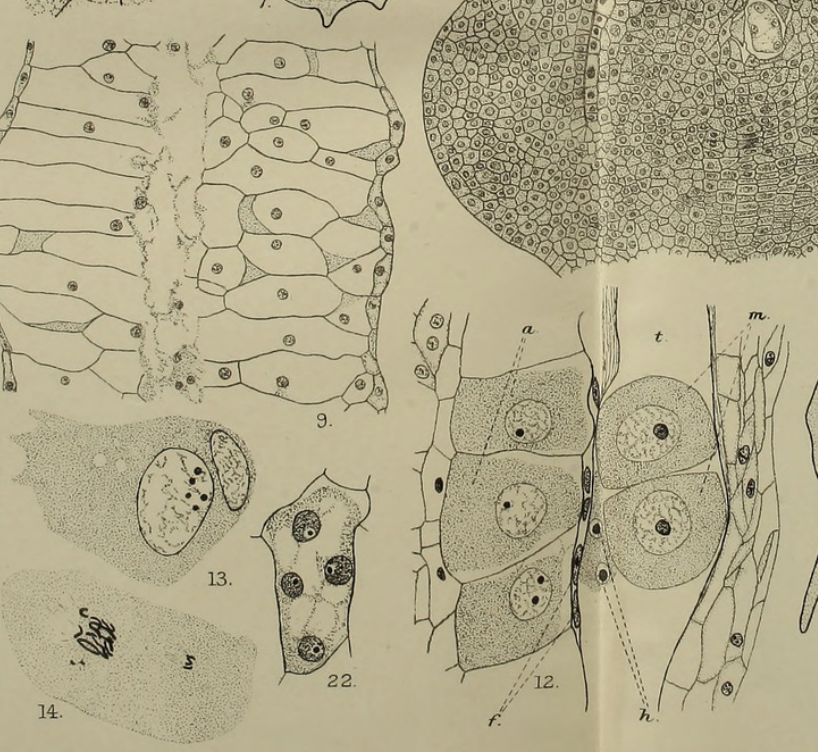

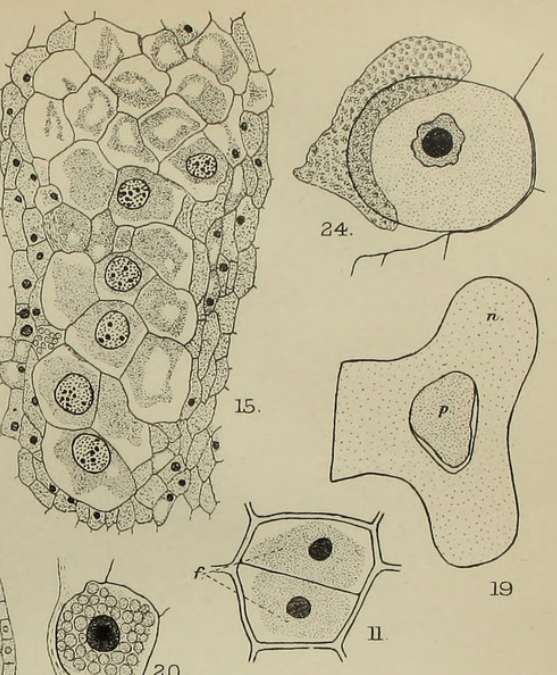


Anrats of Botany,

Vol.XXVII.PL.XXVI.
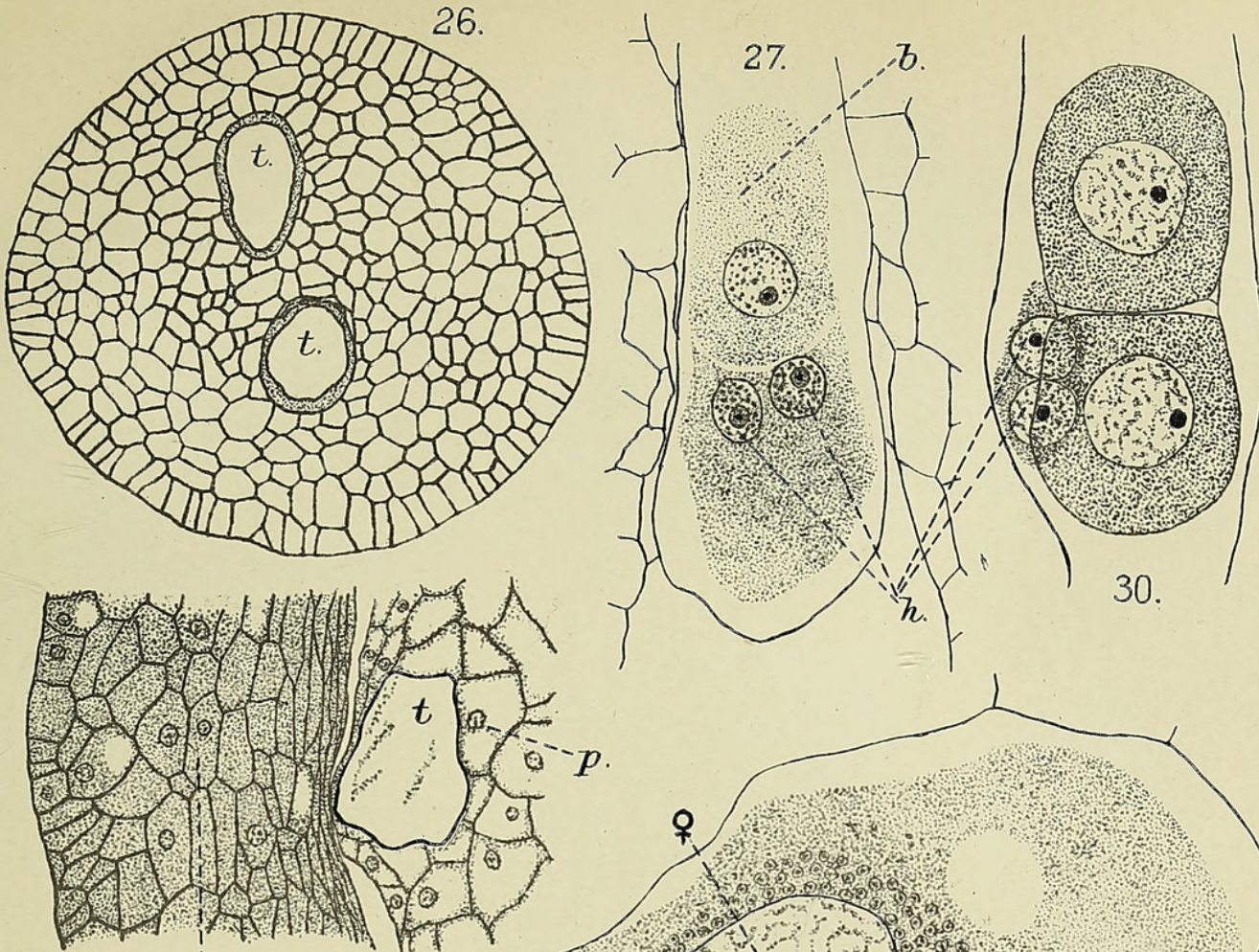

29
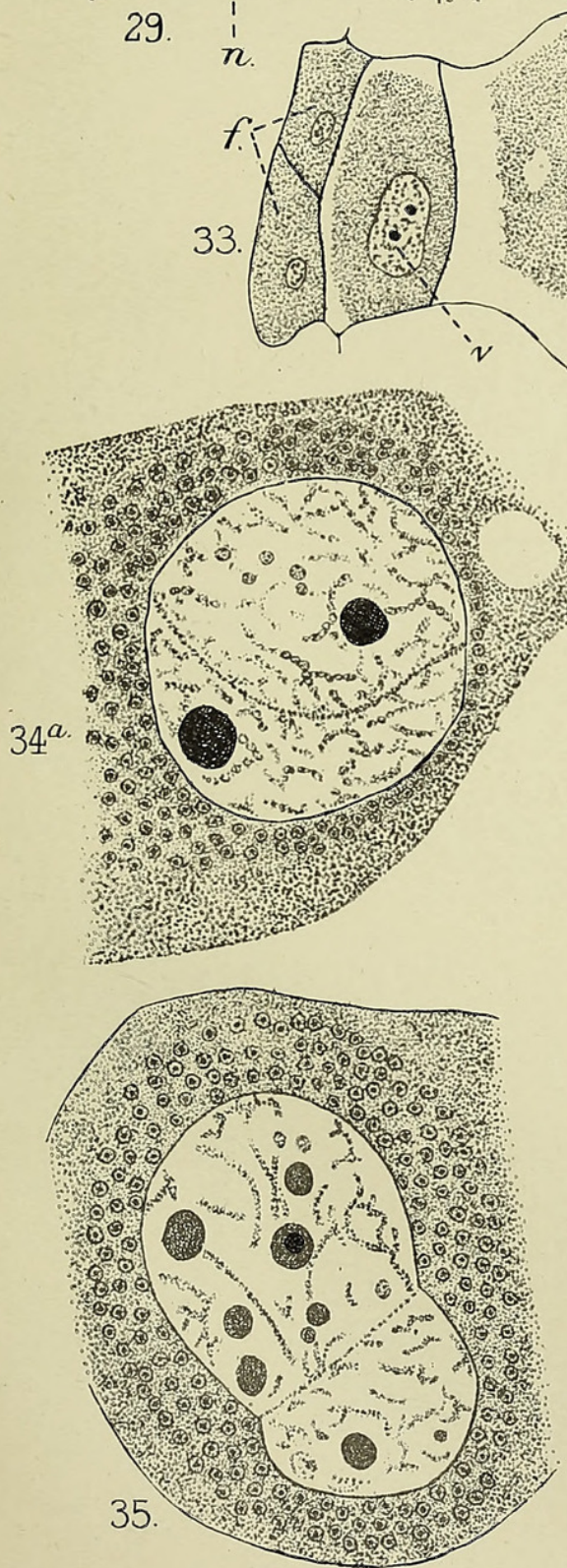

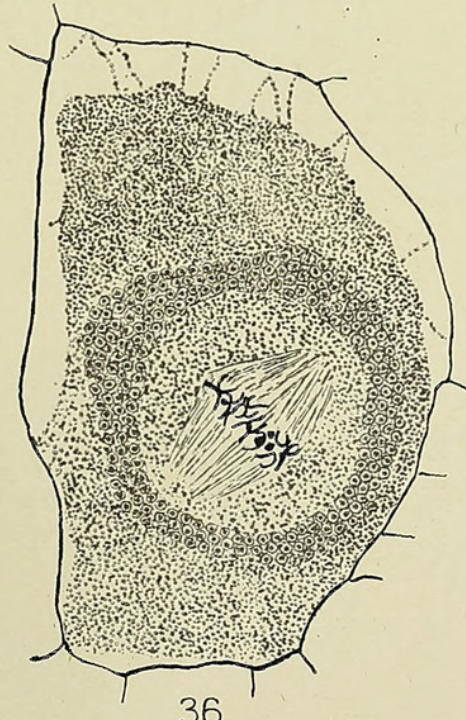

36.
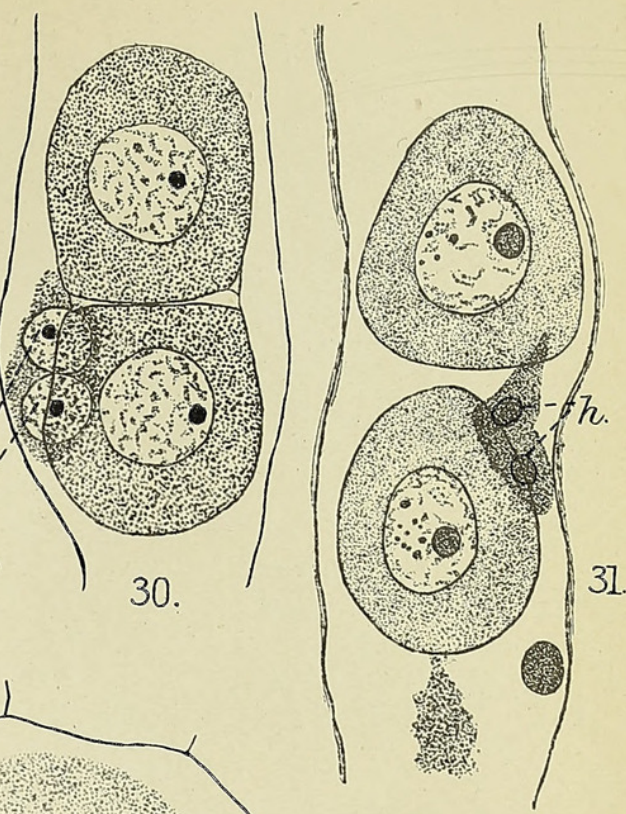

31.

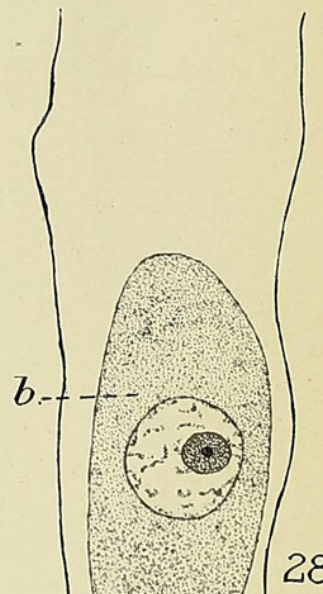

28.

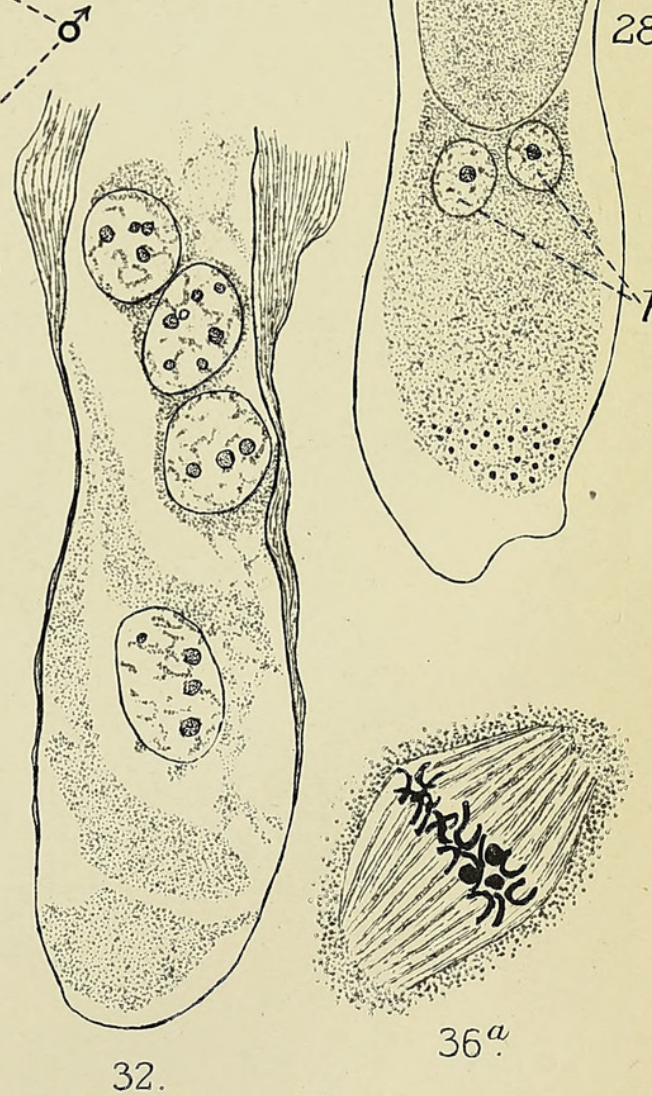


Anrats of Botary,

Vol.XXVII. PL.XXVII.
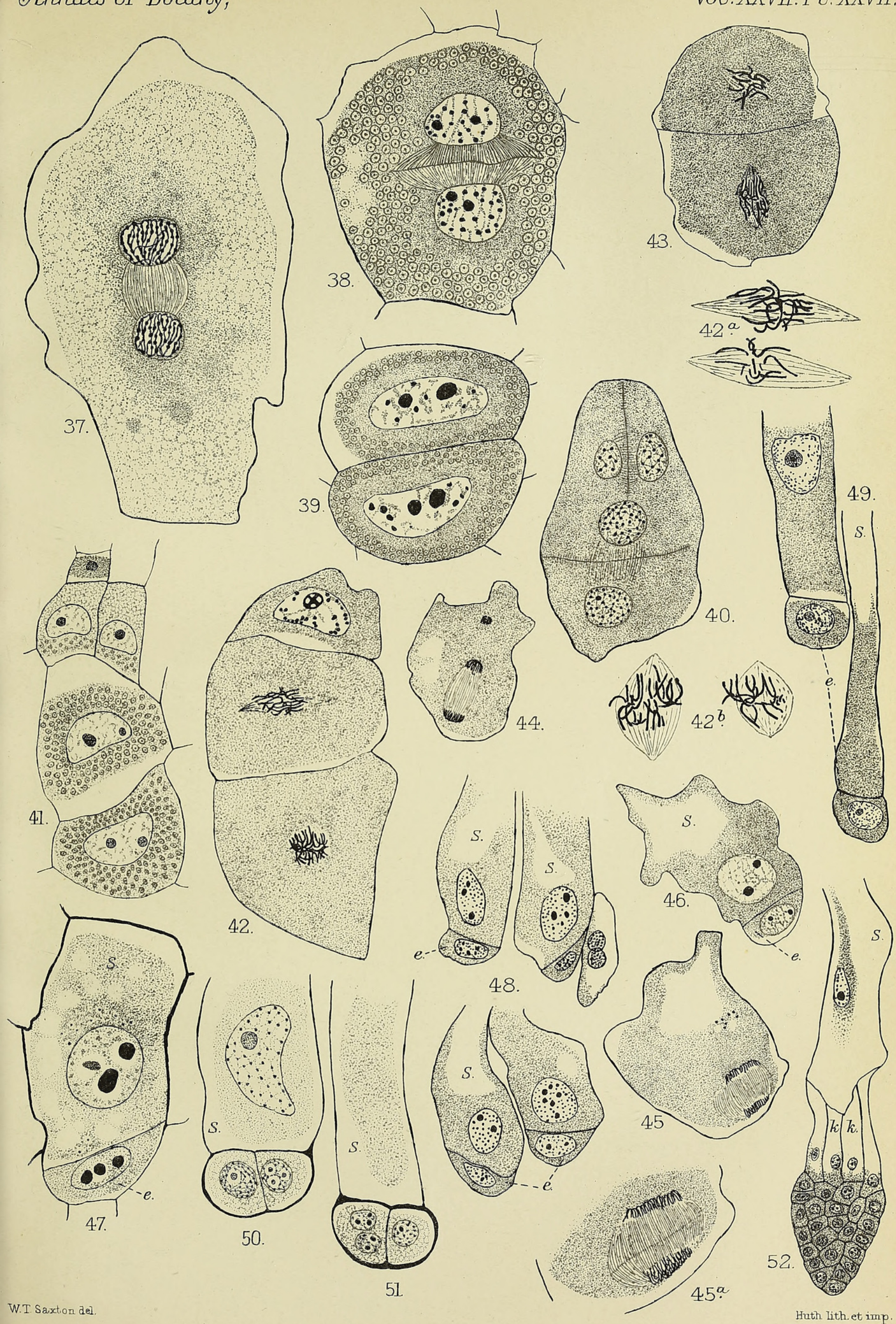

47.

W.T. Saxtion del. 
Annals of Botany

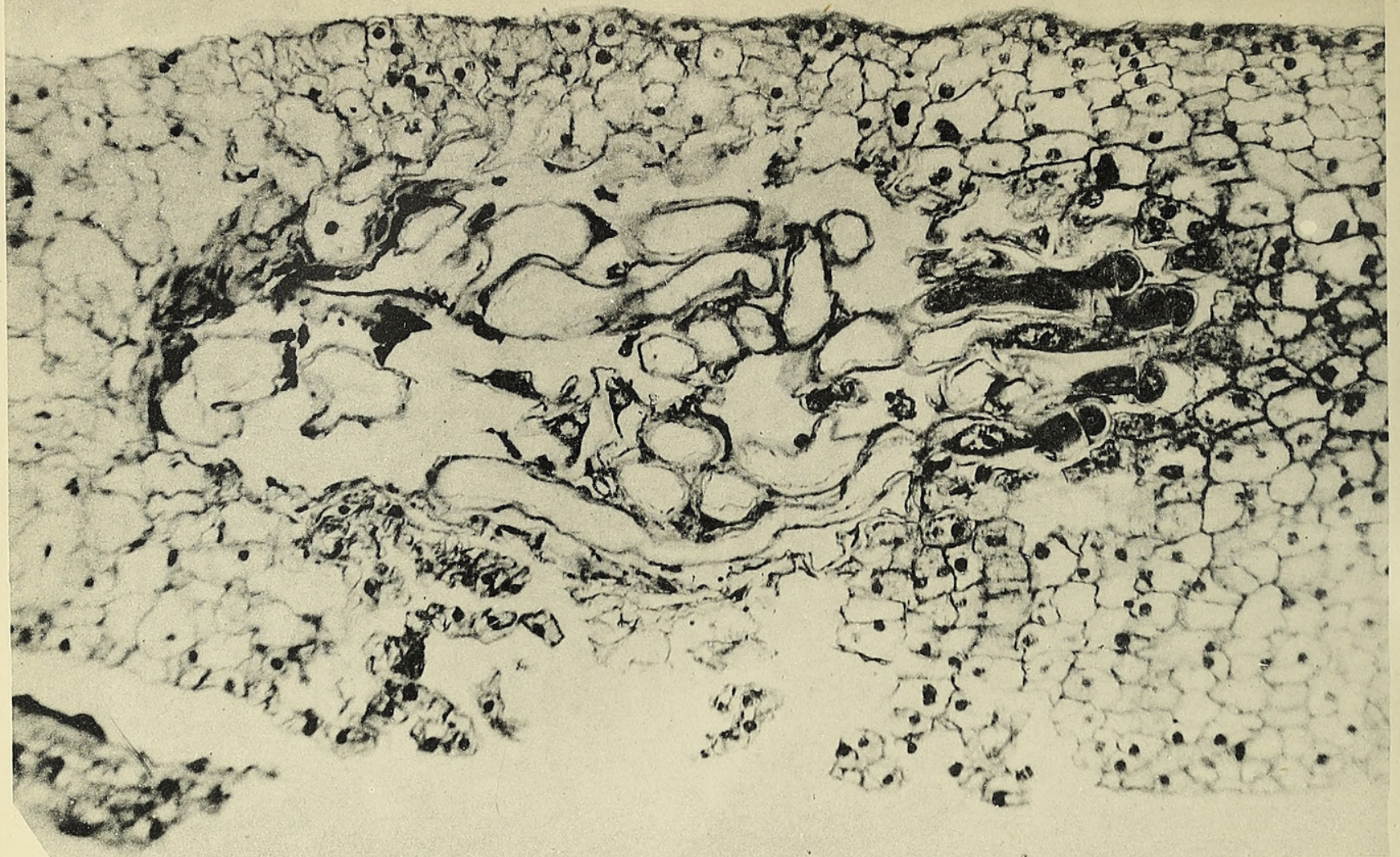

54.

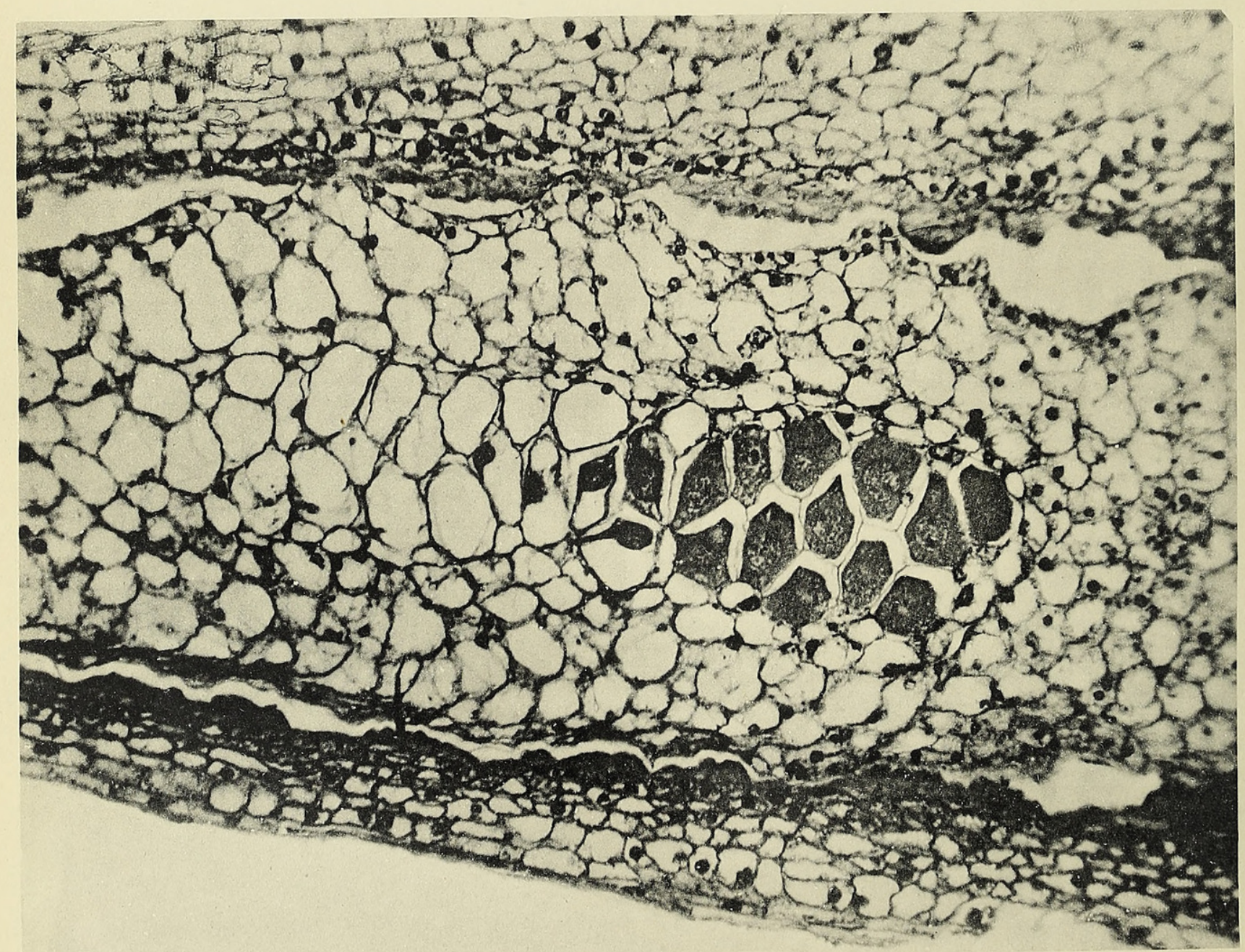




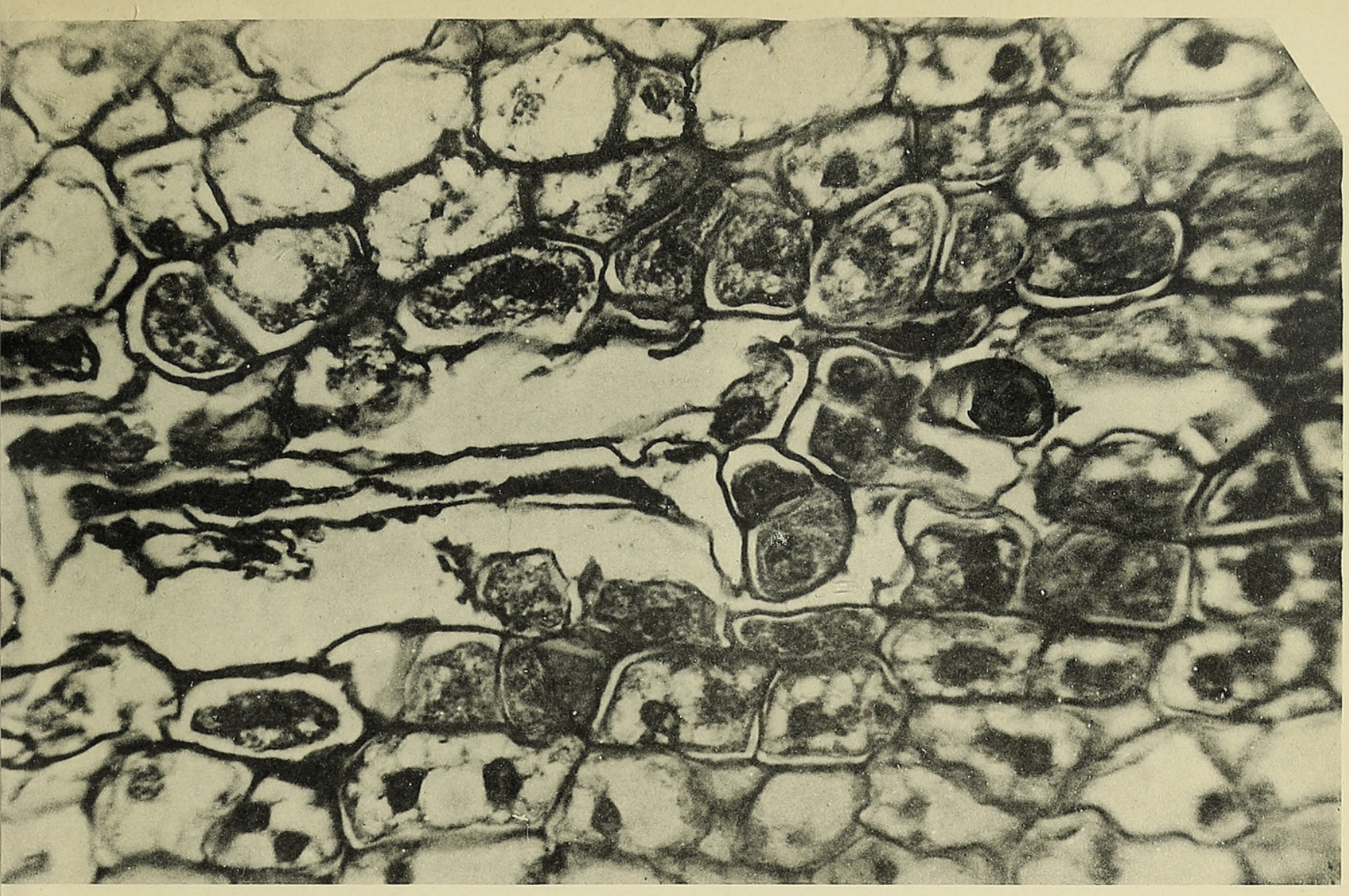

55.

- 3 -

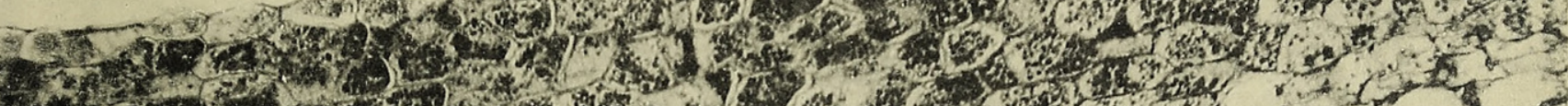

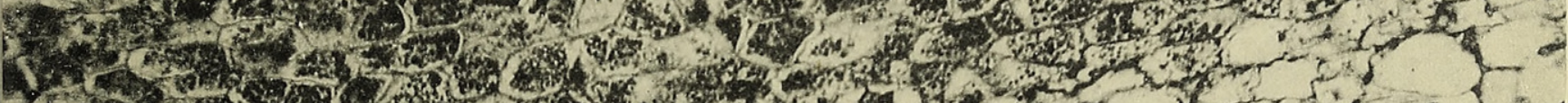

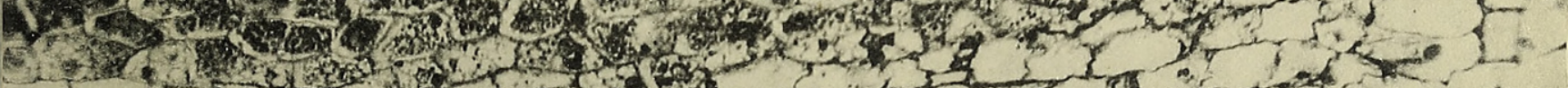

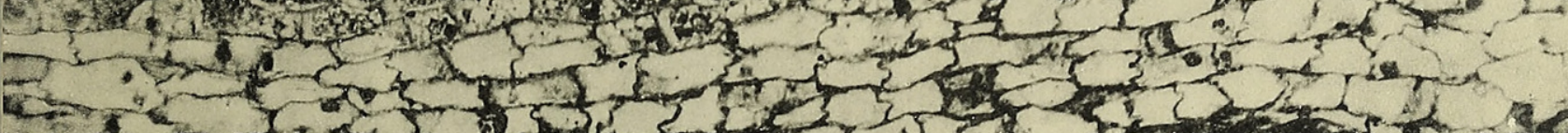

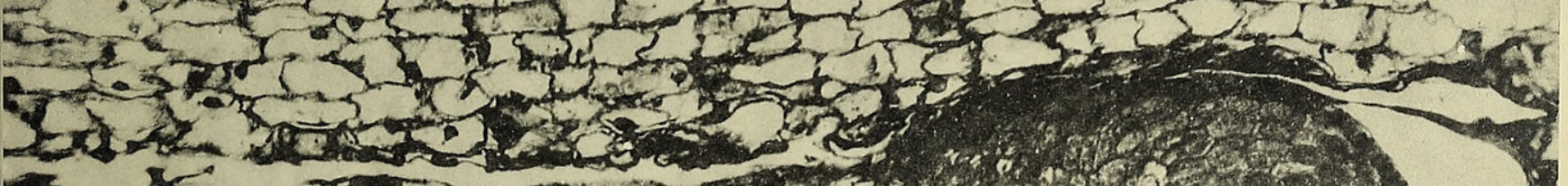
3 -

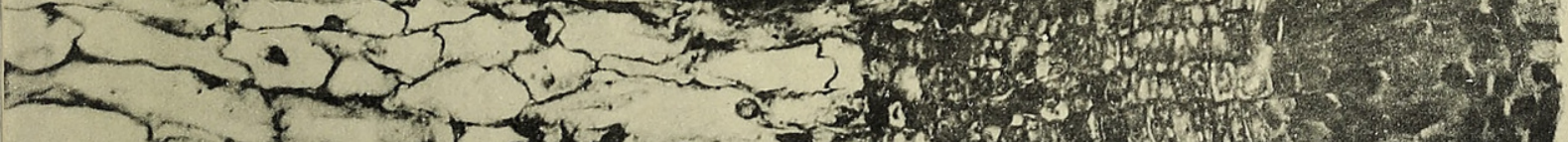

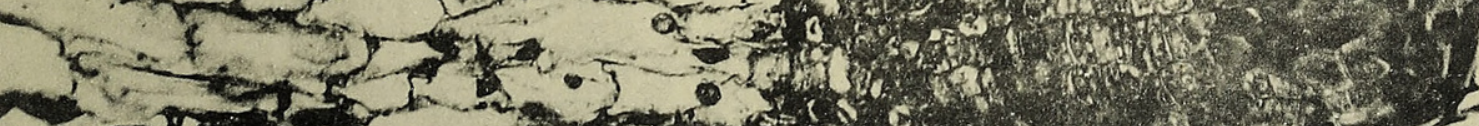

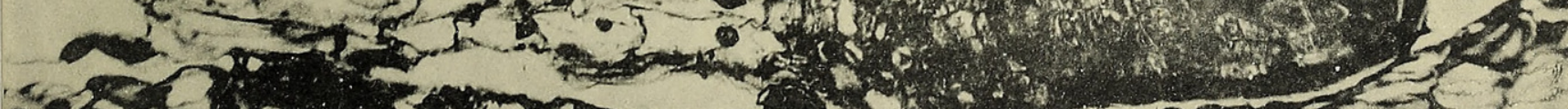

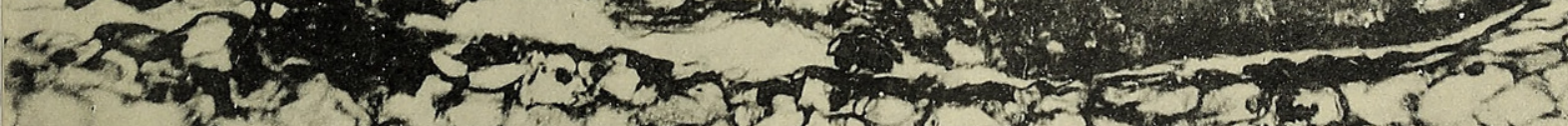

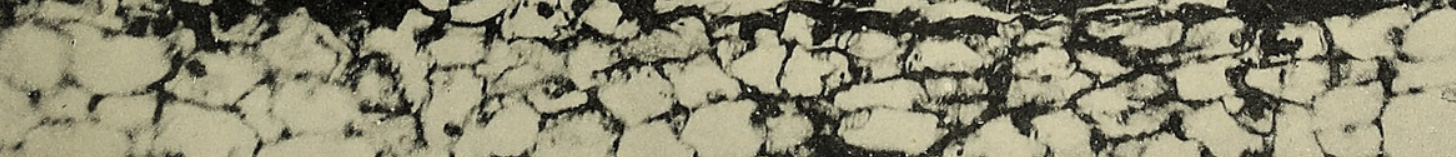

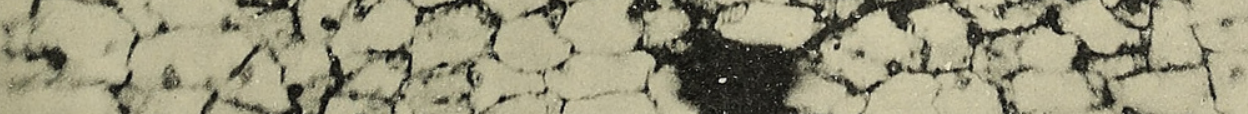

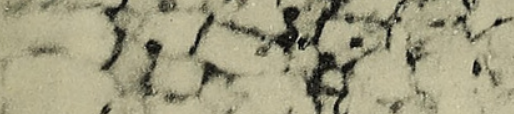
r.t.

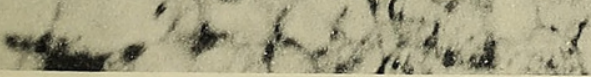

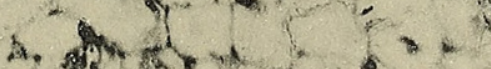




\section{$2 \mathrm{BHL}$ Biodiversity Heritage Library}

Saxton, W. T. 1913. "Contributions to the life-history of Actinostrobus pyramidalis, Miq." Annals of botany 27, 321-345. https://doi.org/10.1093/oxfordjournals.aob.a089461.

View This Item Online: https://www.biodiversitylibrary.org/item/237410

DOI: https://doi.org/10.1093/oxfordjournals.aob.a089461

Permalink: https://www.biodiversitylibrary.org/partpdf/319974

\section{Holding Institution}

Smithsonian Libraries

\section{Sponsored by}

Biodiversity Heritage Library

\section{Copyright \& Reuse}

Copyright Status: Not in copyright. The BHL knows of no copyright restrictions on this item.

This document was created from content at the Biodiversity Heritage Library, the world's largest open access digital library for biodiversity literature and archives. Visit BHL at https://www.biodiversitylibrary.org. 